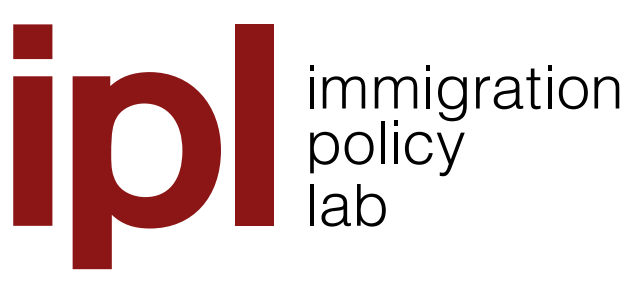

Working Paper Series

Working Paper No. 19-08 • November 2019

The Labor Market Effects of Mexican Repatriations: Evidence from the 1930s

Jongkwan Lee, Giovanni Peri, and Vasil Yasenov 


\title{
The Labor Market Effects of Mexican Repatriations: Longitudinal Evidence from the 1930s*
}

\author{
Jongkwan Lee Giovanni Peri $^{\ddagger} \quad$ Vasil Yasenov ${ }^{\S}$
}

October 16, 2019

\begin{abstract}
We examine the labor market consequences of an extensive campaign repatriating around 400,000 Mexicans in 1929-34. To identify a causal effect, we instrument county level repatriations with the existence of a railway line to Mexico interacted with the size of the Mexican communities in 1910. Using individual linked data we find that Mexican repatriations reduced employment of native incumbent workers and resulted in their occupational downgrading. However, using a repeated cross section of county level data, we find attenuated and non-significant employment effects and amplified wage downgrading. We show that this is due to selective in- and out-migration of natives.
\end{abstract}

JEL Codes: J15, J21, J61, N32.

Keywords: Mexican repatriations, Great Depression, employment, immigration, railway.

${ }^{*}$ We thank Leah Boustan, Breno Braga, Michael Clemens, Stefano Della Vigna, Arindrajit Dube, Katherine Erickson, Francesco Fasani, Daniel Hamermesh, Suresh Naidu, Alan Manning, Chris Meissner, Kris Mitchener, Santiago Perez, Sarah Quincy and seminar participants at the Urban Institute, Santa Clara University, UC Davis, 2017 CEPR/IZA Annual Symposium in Labour Economics, 2018 WEAI International Conference, 2018 SOLE Annual Meeting for helpful comments. An earlier version of this paper was circulated under the title "The Employment Effects of Mexican Repatriations: Evidence from the 1930's." Emily Culver, Justin Wiltshire and John Blanchette provided excellent research assistance. We have not received any financial support for this paper. All errors are our own.

${ }^{\dagger}$ Department of Knowledge Economy, Korea Development Institute. 263 Namsejong-ro, Sejong 30149, South Korea. E-mail: kwanlee@kdi.re.kr

${ }^{\ddagger}$ Department of Economics, UC Davis and NBER. 1153 Social Sciences and Humanities, Davis, CA 95616, USA. E-mail: gperi@ucdavis.edu

$\S$ Immigration Policy Lab, Stanford University and IZA. Encina Hall West, 417 Galvez Mall, Stanford, CA 94305, USA. E-mail: yasenov@stanford.edu 
"The large alien population is the basic cause of unemployment."

- Martin Dies, House of Representatives Member, 1930

"It is the purpose of the Department of Labor...to foster, promote, and develop the welfare of the wage earners of the United States, ... and to advance their opportunities for profitable employment; and it is a mere corollary of this duty and purpose to spare no reasonable effort to remove the menace of unfair competition which actually exists in the vast number of aliens."

— Harry E. Hull, Commissioner General of Immigration, 1931

\section{Introduction}

At several points in US history, especially when workers experienced economic hardship, politicians have proposed the idea that repatriating immigrants could solve or alleviate their problems. In the period 1929-34, as the Great Depression was pushing large number of Americans into unemployment, this idea was pursued on a large scale. Organized efforts mostly by local and state governments with the approval of the federal authorities and with help from local charities and the Mexican government, resulted in the "repatriation" of around 400,000 first and second generation Mexicans. ${ }^{1}$ This figure corresponds to about one third of the total Mexican population in the US at the time (Gratton and Merchant, 2013). Between one fourth and one third of these repatriates were US-born, second-generation immigrants and hence US citizens. The distinction between "legal" and "illegal" foreign-born was overlooked as the programs targeted people of Mexican origin, even when they were US-born citizens. This episode has recently been considered a grave violation of civil rights (see Johnson (2005) and the book by Balderrama and Rodríguez (2006)).

The explicit goal of the program was to reduce the local economic burden brought by Mexicans, and to create jobs for the local population of natives by removing Mexicans who were "taking away" labor opportunities. The justification of the repatriations as a way of

\footnotetext{
${ }^{1}$ Some estimates (Balderrama and Rodríguez, 2006) indicate a number of repatriation as large as one or two million. The numbers we report in the text seem however more likely.
} 
improving the local labor market conditions was very clearly stated by the politicians of the time. For instance, this message was clearly conveyed in the two quotes from Congressman Martin Dies and Commissioner Harry Hull displayed above.

In this paper we use US census data from 1930 and 1940 to analyze whether there is support to the claim that in counties where Mexican repatriations were a larger fraction of the local labor force, native workers experienced improved employment conditions. We exploit the substantial variation in the incidence of deportation of Mexicans relative to the local population across counties. Those were driven by differences in the size of local Mexican population and differences in the ease/cost of repatriation across communities. The most intensive period of Mexican repatriations were the years 1929-34 (Hoffman, 1972). We measure the intensity of repatriation across 686 US counties in states near the border, as the total decrease of the Mexican adult population between 1930 and 1940 relative to the total adult population in 1930. Our main outcomes are changes in employment and in occupation-based wages for native individuals. As local economic conditions could affect both repatriation intensity and employment outcomes of natives, we use an instrumental variable strategy. Our instrument is based on the presence of settlements of Mexicans across US counties in 1910, and the county distance from railway lines to Mexico in 1930. The first variable measures the potential for repatriations, relative to local population. The second one captures the ease of repatriation, as direct rail connections to Mexico reduced costs of and increases opportunities for deportations.

While the distance of a railway from a county can be correlated with past economic conditions, its interaction with earlier Mexican settlement is more likely to be exogenous. Moreover, we explicitly control for the presence of a railway line towards Mexico and hence we identify the impact only on the interaction term. We also control for a large set of economic characteristics targeted at specific potential confounders. First, we include a series of county level controls aimed at capturing local severity of the Great Depression (Fishback et al., 2005) together with a Bartik (1991) index controlling for the presence of the hardest 
hit industries. Second, we include a control for the generosity of New Deal policies, which were implemented in response to the Great Depression. Third, we add extreme weather variables, as some counties were affected by events such as the Dust Bowl or droughts during this time period. Finally, to proxy for local social and crime issues we control for the presence of police forces. The inclusion of the whole set of control variables does not affect our main results. To assuage further concerns of omitted variables bias we verify that our instrument is not correlated with economic outcomes in the decades 1910-20 and 1920-30 preceding our analysis.

Armed with this explanatory variables, controls and instrument we perform two types of empirical analyses. First, we use the individual linked data for natives in the 1930 and 1940 censuses from Abramitzky et al. (2012) to estimate the impact of Mexican repatriations on individuals in border states in 1930 independently from where they were in 1940. This method ensures accurate measurement of the effect on incumbents, is unaffected by composition changes, and controls carefully for invariant and unobserved individual level characteristics. While we can match about $30 \%$ of the male population, we show that this group is not significantly different from the general population, albeit somewhat more educated. We also assert that the matching probability across counties is uncorrelated with our instrumental variables, hence unlikely to introduce systematic bias in our estimates. Second, we use a repeated cross section of the total count of natives from the 1930 and 1940 censuses, and we construct the changes in outcomes at the aggregate county level. This analysis yields an estimate of the aggregate effects on native employment and wages, but is subject to contamination due to change in composition of natives, and misses potential effect on workers who moved out of the county.

Three main results emerge from these analyses. First, an increase of local repatriation of Mexicans by one percent of the 1930 county population produced a decline in the incumbent natives' probability of having a job in 1940 by $0.2-0.3$ percent and a decline in their occupation-based wage by 0.3 percent. This impact was even larger for less skilled natives. 
Second, when analyzing aggregate labor market outcomes, the impact on employment was insignificant and the one on occupational wages was negative and large - a 0.9 percent decline. Finally, we show that a large and selective inflow of low-skilled natives in response to Mexican repatriations is consistent with the difference between the estimated individual and aggregate effects. The change in the local composition of natives coupled with selective in-migration confound the individual results leading to an attenuated employment effect (as unskilled moved in) and an amplified occupation-based wage effect (as new comers were negatively selected in terms of wages).

To rationalize the negative employment and wage effects on incumbents it is important to note that Mexican workers were overwhelmingly employed in "low-skilled" occupations, such as "laborers" and "farm laborers." Their departure likely produced a decline of those sectors, intensive in these type of workers, with local firms likely leaving, and demand for labor collapsing. Rather than a straight complementarity effect (which may have been present) the negative effect may be due to the departure of other factors specific to unskilled sectors (e.g., entrepreneurship) which also reduced demand for natives. We also do not find evidence that other immigrants replaced the departed Mexicans. Overall, these results serve as a reminder of the importance of analyzing labor market effects on natives not polluted by changes in local composition and selective in- and out-migration. More generally, our results suggest that the simple labor market model with perfect substitution between native and immigrants and lack of labor demand effect does not successfully explain the way labor markets operated in this episode.

A natural question is whether this very special episode during the extreme economic conditions of the Great Depression has external validity and is able to teach us something general about the impact of forced repatriation on local labor markets. While the 193040 period has some specificity, there are a few reasons that the lessons learned may also be applicable to more other repatriation episodes (e.g., the increased deportations under the Obama administration and the surge in enforcement efforts since Trump took office). 
First, while the Great Depression occurred during this period, the years 1930 and 1940 were comparable in that the GDP was close to its long run trend, with a deep recession and a big recovery in between. Second, given the high unemployment rate, the claim that their jobs could be taken by non-employed Americans seems at its strongest during this period. ${ }^{2}$ The advantage of analyzing this episode is that we can learn the medium and long run effects of an extensive repatriation program, obtaining a useful test of the claim that this practice is an effective way to increase native employment. As for the specificity of Mexican employment during this period, let us note that in 2017 40\% of Mexicans were employed in the two lowest skill occupations ("Laborers and Farm Laborers" and "Service Workers"), while for natives this number was $18 \%$. When classifying the next two occupational categories ("Craftsmen" and "Operatives") as low-skilled, these numbers change to $72 \%$ for Mexicans and only $36 \%$ for natives. So in spite of the fact that overall the labor force had moved to more skilled jobs, in 2017 the Mexicans were still employed as low-skilled workers in a disproportionate share relative to natives, much as they did in 1930.

This paper offers several novelties relative to the existing literature. First, we use variation in repatriation costs and earlier Mexican settlement to proxy for repatriation intensity. This new instrument goes beyond the commonly used and recently criticized "shift-share" design (Jaeger et al., 2018). We show that it has good first stage power and passes validity tests. Second, by analyzing individual and aggregate data, we show the importance of isolating effects on employment and wages from composition and selection effects. Due to data limitations this type of analysis is done in very few studies analyzing the effect of immigrants in Europe (Foged and Peri, 2016). The third novelty is that this is one of the very few papers focusing on the impact of repatriations/deportations on local markets. Many studies assess the labor market impact of inflows of immigrants to the US and some of them, such as Borjas and Katz (2007); Card and Lewis (2007) and Monras (2018), focus specifically on Mexican immigrants. Most papers, however, use variation in their inflow and focus on immigration in

\footnotetext{
${ }^{2}$ Especially during the peak repatriation years of 1932-34 the unemployment rate in the US was higher than $20 \%$.
} 
the post-1960 period. Episodes that produced sudden and localized immigrant inflows to the US, such as the Mariel Boatlift, have also been objects of intense study among economists (Card, 1990; Borjas, 2017; Peri and Yasenov, 2019). They are considered valuable "natural experiments" which allow scholars to isolate likely causal effects. Alternatively, other causal identification of the impact of immigrants on local labor markets has come from exploiting changes in the supply of immigrants constructed using shift-share proxies based on past immigrant location (Card, 2001) or on combinations with policy changes such as the changes in the H1B visa quotas (Kerr and Lincoln, 2010; Peri et al., 2015). Most of these papers find only small effects of immigration on native employment and wages, on average and also specifically on less skilled native workers. Several studies have provided explanations for the lack of displacement and competition effects of immigrants, such as complementarity of abilities (Ottaviano and Peri, 2012), productivity-enhancing specialization (Peri and Sparber, 2009), choice of appropriate technology (Lewis, 2011) and positive local demand effects (Hong and McLaren, 2015).

Rarely have researchers used repatriation of immigrants to analyze the reverse impact on natives. The importance of such analysis is multi-faceted. First, the impact of removing immigrants who are integrated into the labor force can be different from, and possibly not symmetric to, the impact of adding them. There are different costs of integrating and separating workers, each disrupting production, and they may work different ways. Second, given the large economic and human costs of deportation-based policies, it is important to test whether there is any evidence suggestive of the promised labor market benefits to natives. Clemens et al. (2018) have recently analyzed the effects of the repatriations following the end of the Bracero program, when almost half a million agricultural workers from Mexico were excluded from the US labor market. The authors find no significant effects on employment and wages of native agricultural workers. They argue that capital-intensive technology and crop adjustments played a key role in absorbing the labor change, hence not significantly affecting labor market outcomes for natives. Their study has the advantage of focusing 
on agricultural workers with the ability of analyzing certain specific channels of adjustment. However, such a specific policy may have limited external validity for the economy as a whole. The Bracero program and the subsequent repatriations affected mostly the agricultural sector. In contrast, the repatriations of the 1930s involved many urban communities with large cities, whose economies were already based on manufacturing and services. ${ }^{3}$ Hence, we view our paper as complementary to, and extending the analysis of Clemens et al. (2018).

The rest of the paper is organized as follows. Section 2 outlines the historical context and presents some details about the Mexican repatriation program. Section 3 describes the data we use to measure Mexican repatriations and to construct the instrumental variable and the labor market outcomes of natives at the county and at the individual levels. Section 4 explains our identification strategy and Section 5 outlines the empirical specifications. Section 6 presents the results while section 7 reconciles individual and local labor market level findings. Lastly, Section 8 concludes.

\section{Historical Background}

Immigration from Mexico to the US grew in the early 20th century, driven largely by employers recruiting workers for jobs in railroad, meatpacking, steel mills and agriculture. Prior to 1924, immigration from Europe was much larger and quantitatively more important. With the Immigration Act of 1924 imposing quotas on Europeans but not on natives of the Western Hemisphere, in-migration from Mexico grew robustly and steadily through 1929. In this period Mexican immigrants were among the most recently arrived and ethnically different from the native population. Hence they were the first to be targeted once the public sentiment toward immigration turned sour.

As the Great Depression hit the US economy in 1929, local labor, media and political groups pressed for - and organized themselves to help with - repatriation of Mexicans and

\footnotetext{
${ }^{3}$ For instance, authorities in Los Angeles, CA and East Chicago, IN, were among the most active enforcers of deportations. The aggressive repatriation program in East Chicago, IN, has been noticed and described by several historians such as Simon (1974).
} 
Mexican Americans (Balderrama and Rodríguez, 2006). Using data from ports of entry in Mexico, Hoffman (1972) estimates that over 400,000 Mexicans left the US between 1929 and 1937. Other sources (Balderrama and Rodríguez, 2006) claim much higher levels (up to one million, in some sources even two million), but with little support in the official statistical records. ${ }^{4}$ The more reliable estimates imply that, of the around 1.3 million Mexicans in the US, about 400,000 were repatriated during this period. This figure constituted about $30 \%$ of the Mexican population present in the US as of 1930. It also represents about $1 \%$ of the total 1930 labor force, hence a non-trivial shock, even at the aggregate level.

In most cases, these repatriations were encouraged or forced, mainly by local authorities. They encouraged, pressured and harassed local Mexicans into returning, provided free trains tickets, and sometimes coerced them (at least partially) to leave their US homes (Balderrama and Rodríguez, 2006). Few cases were actual deportations carried out by the federal government, but it allowed local and state agents to act in a forceful manner in promoting repatriation. In several cases, at least in the early years, charities and the Mexican government aided with repatriations, with the idea that this would improve the economic well-being of Mexicans and rejoin them with their people and country. Progressively, however, local authorities became more aggressive, even for those cases classified as "voluntary." Only recently have some US states recognized their role in violating civil liberties and coercing even citizens into repatriation. For instance, in 2005 the state of California passed the "Apology Act for the 1930s Mexican Repatriation Program" officially recognizing "unconstitutional removal and coerced emigration of United States citizens and legal residents of Mexican descent."

A very clear feature of the repatriation program was its strong predication on the economic cost of Mexicans and their causal role in increasing local unemployment. Somewhat inconsistently the two main reasons adduced by Secretary of Labor William Doak for repatriation were that (i) "it was essential to reduce unemployment of citizens," and (ii) "many of

\footnotetext{
${ }^{4}$ See Gratton and Merchant (2013) for a summary of aggregate figures.

${ }^{5}$ A memorial plaque was placed in LA Plaza de Cultura y Artes in Los Angeles claiming that "an estimated 2 million people of Mexican ancestry were forcibly relocated to Mexico" during the Great Depression.
} 
the target individuals were jobless and on relief" (i.e., receiving some form of public or charity assistance) (Hoffman, 1972). This oft-repeated claim of a beneficial effect of repatriation on unemployment was behind the involvement of local authorities and charities. Such an effect was simply self-evident in the statements of most bureaucrats and politicians of the time. Yet the repatriation program would eventually be criticized for violating civil liberties and personal freedom, and for having overall negative social consequences. Evaluating whether the underlying economic motivation was sound is, therefore, critical.

The main time period we are considering (1930-40) includes the Great Depression, a deep disruption of the activity across many localities and industries. Other studies (Boustan et al., 2010; Fishback et al., 2005) have shown that local weather conditions (e.g., extreme events such as the Dust Bowl and severe droughts) and the generosity of the New Deal have also resulted in large local economic effects and in internal labor mobility. We include all these variables, as well as state fixed effects, as controls to assuage the concern that they may be correlated with Mexican repatriation and local economic conditions. Notice that the focus of our analysis is not isolating the effect of coerced removal of labor. Instead, we are interested in the economic impact of many Mexicans and Mexican Americans leaving the US economy at a rate and following a geographic pattern which were very different from other migrants who returned on a strictly voluntary basis. Moreover, as already mentioned, the fact that during the Great Depression the unemployment rate increased to more than $20 \%$ implies that this should have been the ideal case to free some jobs that native workers would take. Therefore, one can argue that this episode should produce an upper bound of the beneficial employment effect of repatriation. 


\section{Data and Summary Statistics}

\subsection{Sources, Sample and Repatriation Intensity}

Our primary data sources are the 1930 and 1940 US censuses. We use both the Integrated Public Use Microdata Series (IPUMS) full/complete count (Ruggles et al., 2019) and the linked individuals versions (Abramitzky et al., 2012, 2014, 2019). The linked data follows individuals by matching records from the 1930 and 1940 censuses based on first name, last name and year of birth. We aggregate the full count data at the local labor market level to create observations for each locality before and after the repatriation program. To verify labor market pre-trends and construct our instrumental variable we also rely on the 1910 and 1920 US censuses. Lastly, we use county level data on several control variables, including some measure of Great Depression intensity such as the decline in retail sales between 1929 and 1932, a variable capturing New Deal spending and one measuring extreme weather events (e.g., the Dust Bowl) from Fishback et al. (2005).

The geographical units that we use to analyze the effects of Mexican repatriations on native individual outcomes are counties. They represent finer geographical entities compared to both state economic areas and commuting zones which are often used to define local labor markets in more modern settings. In our case, the choice of county as a geographical unit is dictated by several considerations. First, such fine geographical detail allows us to maximize the spatial variation of the intensity of Mexican repatriation. More importantly, this choice is related to the way we construct our instrument which is based on the close proximity with railway lines to Mexico. The proximity to a railway line towards Mexico proxies for the cost of repatriation only if we choose small geographic units. Choosing larger units will greatly attenuate the power of our instrument and result in loss of variation. For instance, every state has a railroad to Mexico. Moreover, as we follow individuals over time even if they move to another county, we do not need to assume that the effects of the county level shocks are geographically contained within the county, at least for the individual level results. Finally, 
several of the historical variables and controls were more likely to be collected at the county level.

Our identifying assumption implies that the repatriation of Mexican workers in the county is the relevant local "shock" for native individual residing in it. County boundaries change over time but in the states included in our sample they remained virtually identical between 1930 and 1940. Another potential disadvantage is that county sizes exhibit significant heterogeneity across states - e.g., they are much smaller in Texas than in Nevada. This may be problematic especially when measuring local presence of a railroad using a binary variable. To this end, in constructing our instrumental variable, we also create a dummy capturing the presence of a railway to Mexico based on geographic distance form the railroad rather than on country boundaries. Finally, as the small size of counties may induce some measurement error in the shock we analyze, and as these errors and the shock themselves can be correlated between neighboring counties, we cluster the standard errors at the state economic area to allow for such correlations. More details on how the instrumental variable is constructed are presented in Section 4 below.

As of the early 1930s the vast majority of the Mexican community in the US resided near the states bordering Mexico. Hence, the repatriation program was most consequential in this region. We therefore focus our analysis on the set of "two-layer" bordering states: California, Arizona, New Mexico, Texas, Louisiana, Oregon, Nevada, Utah, Colorado, Oklahoma and Arkansas. They are comprised of 686 counties which constitute our main sample. Still, the program exhibited very large variations across counties in these states. The presence of and the change in Mexican population between 1930 and 1940 in the states outside of this region is close to null. Therefore, an extended analysis covering the whole continental US would provide little additional useful variation to our analysis. Moreover, this choice of states broadly overlaps with the pre-1848 Mexico territory as claimed in the Treaty of Guadalupe Hidalgo following the Mexican-American war (1846-48). This implies a certain degree of commonality of history and culture for these states. 
Our sample includes working-age (18-65 years old) individuals residing in all 686 counties along the border states as of 1930. Because the repatriation program was carried out on the basis of ethnicity and not citizenship status, we denote individuals as Mexican if either they or one of their parents were born in Mexico. The linked individuals dataset, which we use to measure most outcomes, includes only native people who are matched to the same first name, last name and birth year both in 1930 and 1940. Due to name changes following marriage, this dataset contains information only on men. Also, men with higher socioeconomic status are more likely to be matched possibly because they are more likely to remember their age and report their name with consistent spelling. We compare this sample to the general population in the subsection below. Our initial sample corresponds to the one used in Abramitzky et al. (2012, 2014, 2019) who provide details on the methodology used to construct this sample and on the prevalence of incorrect matches. Here we impose the aforementioned sample selection criteria as of 1930. For instance, we restrict the individual's age to 18-55 in 1930 so that the he will still be under 65 and likely in the labor force by 1940 .

Our main measure of Mexican repatriation is the county level change in the number of working-age Mexican-origin individuals between 1930 and 1940, relative to the total workingage population in 1930. Specifically, for county $c$ the variable is:

$$
\text { Repatriation }_{c}=-\frac{\left(\text { Mex }_{c}^{1940}-M_{e x}^{1930}\right)}{\operatorname{Pop}_{c}^{1930}} .
$$

Notice that, for simplicity, the negative sign implies that higher levels of repatriations are measured as larger positive numbers. We analyze the response of native individuals, originally located in the county, to variations of this measure. To visualize the variation in repatriation intensity across our sample of states, Figure 1 presents a county level map of this variable. Darker shades of gray correspond to higher repatriation rates. The largest Mexican repatriation rates were in counties right at the border while localities further away experienced, on average, lower repatriation rates. However, there is significant idiosyncratic variation as some counties in Colorado, northern California and Nevada had very high repa- 
triation rates, while several counties in Texas and Arizona, much closer to the border, had much smaller rates. Notice that the darkest color counties, corresponding to those in the top quintile of repatriation rates, experienced a decrease in the Mexican population larger than two percent of the 1930 working age population. The largest values among those were in the order of 30-35 percent. These are substantial drops in the local working age population due to repatriations of large local Mexican communities.

The variation in repatriation intensity was significantly affected by two factors: the presence of a direct railroad to Mexico and the size of the pre-existing local Mexican community. In order to construct a measure of the former, we used the Commercial Atlas of the World (1931) which identifies the exact counties through which railway lines ran for each state in our sample. We coded the presence of a railroad to Mexico only if the county hosted a 'major' rail line part of the Union Pacific network. ${ }^{6}$ This binary distinction often involved an element of subjectivity. For the most part, this meant that (i) a county had a rail line that followed the general path broadly toward Mexico on the Union Pacific network and (ii) that line passed near the majority of noted population centers. Alternatively, we measured the distance to the nearest railway to Mexico. See Section 4 for more details on how we use this measure to construct our instrumental variable.

Figure 2 presents a county level map of the border states constituting our sample, overlaying the two factors affecting Mexican repatriation that we will leverage in our instrumental variable approach. Namely, we show the working-age Mexican-origin individuals as share of the total working-age population in 1910. Darker shades of gray correspond to larger values. Additionally, we represent with a black and white line, the major railway lines to Mexico as of 1931. Notice the strong correlation between proximity to Mexico and the size of the Mexican communities in 1910. Moreover, there is also positive correlation between the density of Mexicans and the presence of a railway to Mexico. However, we can also spot counties with railway lines with limited Mexican presence and no railway going through counties with

\footnotetext{
${ }^{6}$ Available from the University of Alabama's Historical Map Archive at http://alabamamaps.ua.edu/ historicalmaps/us_states/states.html.
} 
very large presence of Mexicans. In our analyses below, we will use the interaction of these two factors, the size of pre-existing Mexican community and the presence of railway, to predict intensity of repatriation. Specifically, we will show that imputed repatriation rates are higher in localities with larger pre-existing Mexican community which had direct access to a major railway route to Mexico. We will also argue that this interaction is not correlated with pre-existing economic and demographic features of the county.

Our main outcome variables are the aggregate and worker level change in employment between 1930 and 1940. Wage data is not available in 1930 so we can only measure occupational up/downgrading by using the occupational score or by assigning the mean occupational wage in 1940 to all workers in 1930. The occupational score variable assigns each occupation a value representing the median total income of all persons with that occupation in 1950 . Additionally, we also analyze changes in population and self-employment. When measuring outcomes, we further restrict the sample to individuals who, as of 1930, were not unpaid family workers, not in school, and not employed in the army. All outcomes are measured for natives with no Mexican-born parents.

Several related census variable changes between 1930 and 1940 are worth noting. Of particular significance is the varying definition of labor force between the two enumerations. The modern labor force definition was laid out around the 1940 census in preparation for the World War II draft. In the 1940 census people were considered employed if they worked at least one hour for pay in the previous week. On the other hand, prior to this, employment was recorded as having any gainful occupation on the previous day. Because of these discrepancies, we choose to measure Mexican repatriation intensity by changes in working-age population, which can be consistently defined in 1930 and 1940. For the individual data on natives, we flag workers as employed if they meet the corresponding employment definitions in each census, which is admittedly imperfect. Nevertheless, this will only be problematic if the changing employment definition induced measurement imperfections which also correlated with repatriation rates after controlling for local demographic characteristics, pre-trends, 
Great Depression intensity, etc. In a robustness check with aggregate data, we use changes in native population (instead of employment) as an outcome. Our results are consistent across these two different measures.

\subsection{Summary Statistics}

To have a clearer idea of what segments of the labor market were affected by the repatriations it is useful to compare the occupational specialization of the native and the Mexican workforces in 1930, prior to the repatriation program. Table 1 shows the distribution of Mexicans (Column 1) and natives (Column 2) across nine broad occupation groups ordered by their average hourly wage in 1940. We define the bottom three (service workers, laborers, and farm laborers) as low-skilled, and the rest (managers, professional, craftsmen, sales, clerical and operates) as high-skilled. Low-skilled occupations were associated with lower education, lower literacy rates and more manual-intensive tasks. ${ }^{7}$

The first two columns of Table 1 provide a clear picture of the very different occupational distributions between Mexicans and natives. The former were much more heavily concentrated in the three low-skill occupation groups. While only $38 \%$ of the native workforce was employed in these occupations, for Mexicans this share was 73\%. To the contrary, Mexicans were underrepresented in high-skilled occupations such as clerical, managerial, professional and sales positions. Specifically, the top six occupations (high-skilled) accounted for $62 \%$ of the natives but only $27 \%$ of Mexicans.

In the last column we show the occupational distribution for the sample of 1930-40 linked natives. Unsurprisingly, compared to the general population they are slightly more represented in high-skill occupations ( $71 \%$ vs $62 \%)$. This pattern reflects the fact the sample includes only men who tend to be more literate on average, and possible literacy is a determinant of the probability of identifying one's name correctly (Abramitzky et al., 2012). Nevertheless, the occupational distribution of the linked group of male natives was quite sim-

\footnotetext{
${ }^{7}$ Note that throughout the paper whenever we split the sample into low- and high-skill workers we omit the group of farm managers because it is very heterogeneous and difficult to attribute to either category.
} 
ilar to that of overall natives and drastically different than that of Mexicans. This implies the mechanisms of complementarity (Ottaviano and Peri, 2012), different specialization (Peri and Sparber, 2009) and possible upgrading of natives on the occupational ladder (Foged and Peri, 2016) in response to a change in Mexican immigrants were likely to be at work in the considered labor markets, during this time period. This table suggests that Mexicans look unlikely to be competing for similar jobs. Rather, their contribution to production is in tasks that may complement the jobs of natives. It is even likely that within occupation their job description might have been more manual and less language intensive than that of natives, due to their very low literacy level and poor language proficiency. This would imply a degree of complementarity between Mexicans and natives even within skill groups.

Next, in Table 2 we present more summary statistics from the 1930 census. Panel A summarizes our individual level variables in the full count sample (Column 1), the full count male sample (Column 2) and in the linked individuals sample (Column 3). In 1930 men comprised $50.4 \%$ of the working-age population while the share of black was $12.8 \%$. Next, $68.3 \%$ were married and $95.6 \%$ were literate while about two out of three individuals were in the labor force. Compared to the general population, men were more likely to be in the labor force (92.9\% vs $59.9 \%$ ) while the other demographic characteristics were largely similar. Relative to the male and entire population, our linked individuals sample had fewer blacks, more literate and a higher fraction of students. On average, however, the two samples are not too different in the share of literate, share in school and share in the labor force. We have information on 10.13 million working age individuals (3.50 million employed in a lowor high-skilled occupation) of whom 5.10 million were men (2.58 million employed) and of these 1.48 million were matched in the 1930 and 1940 censuses (0.71 million employed).

In Panel B we summarize our county level variables for all the 686 counties in the states considered. The average repatriation rate is $1.8 \%$ of the 1930 working-age population. Next, the mean illiterate share is $7 \%$, while the share of young (age 18-40) is 64\%. We also report the means of all the variables we use in the full set of controls. For example, the mean 
number of months with extreme weather events (drought or wet) is 8.1 and the average distance to Mexico is almost 431 miles. Lastly, for our instrument, we use the interaction of Mexican population share in 1910 and the presence of railway connecting to Mexico in 1930. About $47 \%$ of counties had such a railway, while the mean share of Mexicans in 1910 is $4.1 \%$.

\section{Identification: Earlier Settlements and Railroad to Mex- ico}

\subsection{Instrument Construction and Power}

If Mexican repatriation rates were randomly distributed across counties, a least square regression of individual outcomes on county level repatriation would produce the estimate of interest. However, it is instead more likely that local economic conditions such as the intensity of the Great Depression and local attitudes were correlated with both repatriation intensity and economic outcomes. If we are not able to fully control for them, this would introduce omitted variable bias. To attenuate this concern we use an instrumental variable strategy. Specifically, as mentioned in Section 3, we leverage the idea that repatriations were likely larger in counties with larger pre-existing Mexican communities as of 1910. Mexican settlements in 1910 were driven by early circumstances, hardly correlated with the economic situation of a county in 1930 (or with the more recent flows which may have encouraged anti-Mexican sentiment), but still affecting the size of the Mexican community in 1930. Moreover, the repatriation intensity of the local Mexican community was likely higher where the cost of repatriation was lower. Building on these two ideas, we construct an IV as the interaction between pre-existing settlements (as of 1910) and current cost of repatriation (presence of railway as of 1931). Once we control explicitly for the presence of railway, several measures of economic conditions in 1930, labor market pre-trends and state fixed 
effects, this interaction is unlikely to be correlated with determinants of economic change in 1930-40.

Specifically, we construct the IV as follows:

$$
I V_{c}=\text { Railway }_{c} \times\left(\frac{\text { Mex }_{c}^{1910}}{\operatorname{Pop}_{c}^{1910}}\right)
$$

The term Railwayc measures presence of a main railway line connecting county $c$ to Mexico as of 1931. It is negatively correlated with the cost of repatriation to Mexico as it was easier and cheaper to encourage or force repatriation if people could board a train going directly to Mexico. The second term represents the Mexican working age population as a share of the total resident population in 1910, measuring the historical local presence of this group. It is positively correlated with the size of current Mexican population, via persistence of migrant networks, and hence correlated with the size of population at risk for repatriation.

We construct two versions of the instrument. In the first version the dummy Railwayc is equal to one if the railway to Mexico goes through any part of county $c$ and zero otherwise. We call this our "Main IV." In the second version Railwayc is a dummy equal to one if there is a railway line to Mexico at a distance less than 4.77 miles from the most populated center in the county. This is the average distance between the center of the county and the railway, in the states excluding Louisiana, Oklahoma, and Texas which contain the smallest sized counties. We call this our "Alternative IV." In this second instrument the presence of a railway does not depend on the size of the county, which may be desirable given the large difference in county sizes between some states in our sample (e.g., California and Texas). Note that, as we explicitly control for presence of a railway and distance to Mexico, the identifying variation in this instrument comes only from the interaction between Mexicans settlements in 1910, and presence of a railway to Mexico in 1931.

Looking at Figure 2 it is evident that there is a correlation between the share of Mexicans in 1910 and the presence of a railway to Mexico in 1931. However, it is also clear that the 
correspondence is not perfect and there is some idiosyncratic variation. For instance, there are some counties in Oregon, Utah and Colorado with only a small share of Mexicans, and a railway line to Mexico. Similarly, there are counties in Arizona with very large share of Mexicans without a direct railway access to Mexico.

Table 3 shows the first stage results from the IV regressions. The independent variable is the main instrument (Columns 1-2) or the alternative instrument (Columns 3-4). The

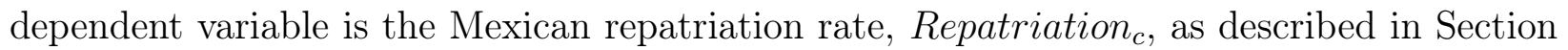
3. Columns 1 and 3 control for our baseline characteristics: the log of population, the Bartik index, the percent of farm land, median occupational wage, distance to Mexico, the presence of a railway to Mexico, the population share of police, the population share of young people and the population share of illiterate all measured as of 1930 and state fixed effects. In Columns 2 and 4, instead, we use the full set of controls, which include retail spending changes 1929-33 proxying for local Great Depression severity, extreme weather events in 1930-40, Dust Bowl indicator and a measure of local New Deal spending (Fishback et al., 2005). Standard errors are clustered by state economic area and shown in parenthesis. In these first stage regressions the units of variation are the counties as they represent the level at which we measure our local labor market shocks.

The coefficients presented in first two columns show that, after controlling for local characteristics and economic conditions, the presence of a railroad to Mexico is associated with a 0.17 percent increase in repatriations. This correlation is statistically significant and the first stage F-statistic is equal to about 19. Similarly, Columns 3 and 4 show that, all else equal, a 'close' railway line, at fewer than 4.77 miles from the population center of the county, leads to a 13 percent increase in repatriations. The first stage F-statistics for this IV is around 15. The first stage power when using distance radius or county line to identify the presence of a local railway is rather similar. Overall, these results assert the notion that our instrumental variables are reasonably good predictors of Mexican repatriation rates between 1930 and 1940 even after controlling for an array of related characteristics. 


\subsection{Instrument Validity}

The key question for any instrument is whether it satisfies the exclusion restriction. In our setting this amounts to whether the variation produced by interacting railway presence in 1931 and Mexican share in 1910 is uncorrelated with unobserved economic changes in 1930-40 after controlling for distance from railway, distance to Mexico, a full set of controls and state fixed effects. In order to provide some test of this proposition we analyze the partial correlation of the IVs with pre-1930 county level economic trends. In particular we ask whether the proposed IVs are correlated with the 1910-30 or 1920-30 changes in county level employment, population and occupational wage. And when using the linked sample of male individuals, whether the IV is correlated with their internal mobility during the 1920-30 period. If economic changes are persistent, a correlation of the instruments with pre-existing aggregate or individual trends would cast doubt on the exclusion restriction in our setting.

Table 4 shows the results from this exercise. Each panel presents the estimated coefficients from regressions of a separate pre-trend outcome variable denoted in the header on our IVs. Panels A-C use aggregated county level data and Panels D and E use the linked individuals data. Columns 1 and 2 use the main IV and Columns 3 and 4 the alternative one. Next, in Columns 1 and 3 we only include the basic set of control variables, while in Columns 2 and 4 we include the full set. The dependent variable in Panel A is the 1910-30 change in employment, in Panel B it is the 1920-30 change in population and in Panel C it is the 191030 change in occupational wage. In Panel D the dependent variable is a dummy indicating whether the person has moved across counties between 1920 and 1930, and in Panel E it is a dummy for remaining in the same county. In addition to the baseline or full set of controls, the individual level regressions control for personal demographic characteristics - age, race, literacy and marital status, all as of 1930. Standard errors are clustered by state economic area and shown in parenthesis. Lastly, all regressions with aggregate data (Panels A-C) are weighted by local 1930 population size.

None of the estimated coefficients are statistically significant at the $1 \%$ confidence level. 
In Panel A-C the county level pre-trend do not show any significant correlation with the IV. Similarly, in Panel D the probability of individuals of moving within a state between 1920 and 1930 is not associated with the IV. Panel E shows some negative correlation of the IV with the probability of remaining in the same county between 1920 and 1930, but only significant at the $10 \%$ level. The presence of a railway to Mexico interacted with the size of the Mexican community slightly increased the probability of native moving out of the county between 1920 and 1930. In other words, after controlling for a wide variety of economic and geographic factors, our instrumental variables do not seem to be correlated with previously ongoing aggregate economic trends during the 1920-30 decade. For the individual sample there is no correlation with probability of moving within the state but some negative correlation with the probability of staying in the same county, between 1920 and 1930. These results are consistent with the IV mostly satisfying the exclusion restriction.

Another test that we perform to examine the validity of our IVs is to check whether they are correlated with the linking rate of the individual data. If the probability of linking individuals between 1930 and 1940 using the census data across counties is affected by the intensity of repatriation, as proxied by the IV, this would imply that the IV is correlated with differential attrition out of the sample across counties. This may generate spurious results. In Table 5 we regress the percentage of adult male population in 1930 that is linked to the 1940 record, on the IVs. For both the Main IV (first row) and the alternate IV (second row) the data show no correlation between linking rate and the predicted repatriation intensity. While the linked sample is certainly selected, the selection does not seem to be correlated in any way with the explanatory variable.

\section{Empirical Specification}

We conduct two types of empirical analyses - one at the individual worker level using linked data and one at the aggregate local labor market level (see Section 3 for more details). 
In both cases the explanatory variable of interest, intensity of Mexican "repatriation", is measured at the county level. However, in the first case the units of analysis are individual workers followed over the period 1930-40, while in the second case they are consistently defined county aggregates. We now describe in turn the equations estimated in each of the two specifications.

\subsection{Individual Level Data}

Using individuals data from the 1930 and 1940 full count censuses linked as described in (Abramitzky et al., 2012, 2014, 2019) the equation we estimate is as follows:

$$
\Delta y_{i c}^{1930-40}=\alpha_{1}+\beta_{1} \text { Repatriation }{ }_{c}+\gamma_{1} X_{c}^{1930}+\delta_{1} Z_{i c}^{1930}+\lambda_{s}+\varepsilon_{i c} .
$$

The dependent variable is the 1930-40 change in the relevant outcome for individual $i$ who was residing in county $c$ as of 1930 . The individual level outcomes we focus on are employment status and occupational wage/standing. The specification includes also a set of individual

level controls, $Z_{i c}^{1930}$. These variables are age, gender, race, literacy and marriage indicators as measured in 1930. They control for personal characteristics that may affect the evolution of individual labor market outcomes over the 1930-40 period. Any time-invariant individual characteristics, observable and unobservable, that affects the probability of employment or the wage level of an individual is "differenced" out in our approach. The county level controls $Z_{i c}^{1930}$ are those, either "basic" or "full set", described for the first stage regression in Section 4.1. The term $\lambda_{s}$ represents state fixed effects, capturing aggregate state level economic trends of the local labor markets during the 1930-40 period. Lastly, $\alpha_{1}$ is the intercept and $\varepsilon_{i c}$ is the individual error term. Our sample is always restricted to natives who reside in the set of two-layer border states as of 1930. We do not use weights when estimating this equation. The standard errors are clustered at the state economic area level. This more conservative clustering allows for county level shocks to be correlated within a state 
economic area, which is plausible if these larger geographical unit better approximate local labor markets.

\subsection{Aggregate Level Data}

Using aggregate data for counties in 1930 and 1940 obtained from the full count censuses, we also estimate the following equation:

$$
\Delta y_{c}^{1930-40}=\alpha_{2}+\beta_{2} \text { Repatriation }_{c}+\gamma_{2} X_{c}^{1930}+\lambda_{s}+\varepsilon_{c}
$$

The dependent variable $\Delta y_{c}^{1930-40}$ denotes the change in aggregate outcome $y$ for county $c$ over the period 1930-40. The main outcome variables we analyze are employment, population and occupational wage. Note that here changes in the composition of a county population will be responsible for part of the measured change in the outcome. The explanatory variable

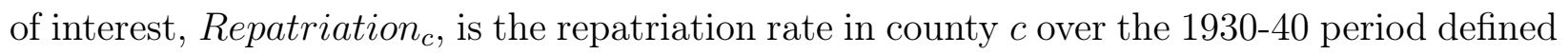
as the county level change in the working-age Mexican population between 1930 and 1940 as a share of the 1930 population (see Section 3). As in the previous regression $X_{c}^{1930}$ represents the set of county characteristics, described as "basic" or "full set" of controls in Section 4.1. Next, $\lambda_{s}$ represents state fixed effects, capturing state level economic trends during the 1930-40 period. Lastly, $\alpha_{1}$ is the intercept and $\varepsilon_{c}$ is the county level error term. The sample is restricted to counties in the set of two-layer border states mentioned in Section 3. We estimate this regression by using the county level population as of 1930 as weights. The standard errors are clustered by state economic area, as in the individual level regressions, to account for correlation in the residuals across counties.

The coefficient of interest in both equations is $\beta$. In order for that to capture the causal effect of repatriation on native individual outcomes, either at the individual or at the county level, we estimate the regression with two stage least squares (2SLS) using the IVs defined in Section 4 above. 


\section{$6 \quad$ Empirical Estimates}

\subsection{Preliminary: County Level Correlations}

Before presenting the results from the individual level regressions, it is useful to show raw county level correlations between the repatriation measure and changes in native labor market outcomes - employment, population and wages. In Figure 3 we plot county level outcomes of natives on the vertical axis against the measure of repatriation intensity (left) or the repatriation intensity predicted by the instrument (right). Each panel shows a separate outcome variable. Each bubble represents a county's and its size is proportional to its working-age population in 1930. The change in employment (population) is calculated as the difference between 1940 and 1930 employment (population) divided by population in 1930 .

Panels A and B show very weak and non-significant correlations between repatriation intensity and employment and population growth of natives. For example, controlling for state fixed effects, the slope in Panel A (left) is 0.07 with a t-statistic 0.4. Panel B which presents the 1930-40 change in native working age population shows a similarly weak and not statistically significant relationship. In other words, there seems to be no significant association between raw repatriations and change in employment (or population) of natives. Similarly, Panel C shows the association between Mexican repatriation and the 1930-40 change in occupational wage. Even in this case the association is weak, and a simple regression shows no significant partial correlation. Overall, these figures do not show correlations consistent with a significant positive effect of Mexican repatriation on native population and employment.

While a long tradition encompassing most studies of the effect of immigrants on natives (Card, 2001, 2005; Peri and Sparber, 2009) considers the average response of local labor market variables to immigration flows, these aggregate correlations should be interpreted with great caution. Certainly, the presence of unobservable local shocks and measurement error can affect the causal interpretation of the estimates, and we will discuss this later. Additionally, however, we want to emphasize that the aggregate effects confound heterogeneous 
responses of incumbents and changes in composition of local labor due to in- and out-flows of native workers. Moreover, by focusing on fixed geographic units such as local labor markets, the effects on natives who move out as consequence of immigrants are lost. In the individual analysis below, we follow workers even if they move out of the county they resided in 1930. This allows us to isolate the exact effect on incumbent workers, which should have been of particular interest to local policy makers in 1930. Moreover, by keeping the group of people fixed it avoids confounding factors such as selection and attrition.

\subsection{Individual Level Regressions}

The main estimates of the coefficient of interest $\left(\beta_{1}\right)$ from the individual regression equation (2) are reported in Tables 6 and 7. In Table 6 Panel A the outcome is the change in the individual employment status between 1930 and 1940. It is equal to one for workers who move from non-employed to employed, zero for no change and minus one for the opposite change. Note that the definition of who counts as employed varies between the two enumerations so this variable may contain some noise. Nevertheless this discrepancy should not be affected by the local presence of Mexicans, hence any measurement error associated with it should be orthogonal to the explanatory variable of interest. In Panel B the dependent variable is a transition dummy from non-employment in 1930 to employment in 1940. This variable is equal to one if such a transition is experienced by the individual and zero if any other transition or no transition at all took place. Next, in Panel $\mathrm{C}$ the outcome is a transition dummy form employment in 1930 to non-employment in 1940 and, lastly, in Panel D it is a dummy for transitioning from any other status into self-employment. Columns 1 and 2 show the 2SLS estimates when using the main IV (interaction of the dummy for a railway in the county with the 1910 share of Mexicans) and Columns 3 and 4, the estimates with the alternative IV (a dummy for a railroad less than 4.77 miles from the center of the county still interacted with the 1910 share of Mexicans). Columns 5 and 6 display the OLS estimates for comparison. Finally, the odd numbered columns include the basic set of controls (see 
above) while the even numbered columns control for the full set of control variables.

The basic estimates presented in Panel A are robust across specifications and imply that an increase in Mexican repatriations by one percent of the 1930 county population in a county decreased the probability of a native to be employed in 1940 between 0.20 and 0.25 percent. In counties with repatriation rates around 15 percent of the population, which would put them in the top 5 percent of repatriation intensity, native individuals experienced a lower employment probability by about 3.4 percent in 1940 relative to a county with no Mexican repatriation. This effect arises mainly from a decreased probability of transiting between nonemployment in 1930 and employment in 1940 (Panel B), while the probability of employment to non employment transitions is not significantly affected by repatriation intensity. The probability of self-employment was also not statistically significantly unaffected. The first result emerging from the individual regressions is that Mexican repatriations reduced the potential opportunities of incumbent natives to find employment.

A comparison with the OLS coefficients show that those estimates are biased towards zero. This could happen if more organized, pro-active and effective repatriation efforts took place in counties that were overall more economically successful. If a weaker local impact of the Great Depression allowed better and more organized efforts to repatriate, our IV would correct for such omitted variable bias. The sign of the effect is consistent with the hypothesis that Mexican workers were complementary to natives, as suggested by the drastically different occupational specialization between natives and Mexicans presented earlier. It is possible that the loss of Mexican laborers had a negative local multiplier (or complementarity) effect on demand for skilled, professional, specialized workers. This left natives with much fewer employment options and unlikely to take one of the laborer, lower paid and more manual jobs freed by the repatriated Mexicans. An alternative channel for these negative effects could be that firms and investors left cities where the Mexican labor was substantially reduced by the repatriation program. Local industries thus experienced collapse of workers and firms and incumbents were left less likely to find a job. 
Table A1 in the Appendix mirrors Table 6 but the underlying regressions are estimated on a sample of black native workers. We find that, on average, blacks experienced more negative employment effects than the general population. In particular, Panel A suggests semi-elasticity in the order of -0.35 to -0.40 . Black native workers are highly concentrated among laborers and farm laborers (48\% in these two occupation groups), and even more concentrated among service workers (37\%). This significant loss in black employment suggests that the departure of Mexicans reduced the employment opportunities in the low-skilled intensive sectors.

Next, Table 7 then shows the estimates on the impact of Mexican repatriations on the occupational wage (or score) of incumbent natives. Note that wage data is not available in the 1930 census so we assign every worker the median occupation wage observed in 1940 for their occupation in 1930. The variable occupational wage (score) captures the wage (percentile) associated to the occupation. An increase in that variable implies that a worker moved to an occupation that in 1940 was better paid. A decrease suggests that she moved to a lower paid occupation. In Panel A the dependent variable is the change in occupational wage between 1940 and 1930. In Panel B it is defined as the log of the ratio of 1940 to 1930 occupational score. The occupational score is computed by IPUMS by assigning each occupation a value representing the median total income of all persons with that occupation in 1950. The estimated coefficients, not always precise, show that the occupational wage declined for natives (not always significantly) in response to Mexican repatriation. Native workers downgraded or failed to upgrade their occupations in cities with a large outflow of Mexicans relative to cities with lower repatriation intensity. This is consistent with the occupational structure of Mexicans relative to natives before 1930. As the jobs occupied by Mexicans were at the bottom end of the occupational skill distribution, natives were likely to replace them in some of those jobs, implying a downgrading of their skills and compensation. Natives were left with fewer employment opportunities and the jobs left by Mexicans, were filled at the expenses of their occupational wages (score). 
The combination of these two effects makes it clear that, for the average native worker the repatriation of Mexicans caused a loss in employment opportunities and occupational wage. While the average effect may hide heterogeneity, which we will analyze below, it is interesting that this is probably what the median US voter experienced as a result of the repatriation program. It is this representative worker who is the main focus of policymakers when designing labor market interventions. The stated objectives of the repatriation program as explained in Section 2 did not seem to materialize and the incumbent workforce did not experience the positive labor market effects that were thought to be a straightforward consequence of the program.

\subsection{Individual High- and Low-Skilled Incumbents}

Next, we move on to examining whether the repatriation of Mexicans had differential effect on high and low-skilled incumbent natives. This exercise is specifically motivated by the differential occupational distribution of Mexican and native workers as discussed earlier. We define low and high-skilled workers based on their occupation in 1930. Specifically, if a worker was employed in the bottom two occupations (laborers and farm laborers) based on 1940 wages they are counted as low-skilled. Otherwise, they are considered a high-skilled worker. See Table 1 and Section 3 for more details.

A standard story of complementarity in production between low and high-skilled (Goldin and Katz, 2009) implies that high-skilled natives suffer stronger negative wage/employment effects from the repatriation of Mexicans, while low-skilled experience positive effects. On the other hand, it is possible that the presence of Mexicans induced local agglomeration of some industries, and attracted firms, physical capital and expertise complementary to lowskilled production (Lewis, 2013). In this case, by shrinking those industries the decline of Mexican workers supply may specifically negatively affect low-skilled natives.

Table 8 presents the results of the impact of Mexican repatriations on labor market outcomes of incumbent native individual workers by skill type. Each entry is the estimated 
coefficient $\beta_{1}$ from equation 2 on a subsample of low- (Columns 1-4) or high-skilled (Columns 5-8) native incumbent workers. Panels A and B display the results for employment outcomes denoted in the headers while Panel C looks at occupational wages. Columns 1, 2, 5 and 6 use the main IV while the rest use our alternative IV. Additionally, the odd-numbered columns include our baseline controls while the even-numbered ones add the full set of controls, both as previously defined. Standard errors are clustered by state economic area and shown in parenthesis.

Panel A shows that an increase in repatriations by a single percent of the 1930 county level population decreased the probability of a low-skilled native to be employed in 1940 by about 0.57 percent. This is a much larger effect than the one observed for the average worker and presented in Table 6. At the same time, high-skilled native experienced lower employment probability by about 0.3 percent. $^{8}$ As shown in Panel B, these patterns are driven by decreased probability of transiting from non-employment in 1930 to employment in 1940. Following a percent increase in repatriation, this probability decreased by about 0.40.5 percent for low-skilled and 0.2-0.3 percent for high-skilled ones. Lastly, Panel C suggests that high-skilled incumbent workers downgraded their occupational standing in response to repatriations. The effect on low-skilled natives' occupational wage is not statistically significant.

Overall, Table 8 suggests that, as a result of the repatriation program, the low-skilled native incumbent workforce experienced larger decreases in the probability of gaining employment relative to the high-skilled workers. These results suggest that a standard model of aggregate production complementarities between high and low-skilled would not successfully explain the impact of the repatriation program. The fact that all groups experienced negative or null effects on employment suggests that a local job multiplier/agglomeration effect is at work. Moreover, it is possible that among less skilled occupations Mexicans and natives

\footnotetext{
${ }^{8}$ Note that, as mentioned above, in all results by skill level we exclude farm managers whom we are uncertain to which group they belong. It is, therefore, not necessary that the estimates from Table 8 average out to the ones from Table 6 .
} 
were still differentiated and complementary. It is more likely, however, that the outflow of Mexicans lead to loss of other complementary factors such as physical capital, expertise and entrepreneurial abilities causing the relative decline of low-skilled intensive industries.

To directly test this idea in Table 9 we analyze the effect of repatriation intensity on the change in the share of employment in low-skilled intensive sectors across countries. ${ }^{9}$ We define low-skilled intensive sectors as those in which the share of workers in the bottom three occupations is above the median in 1930. Consistently with the idea of agglomeration economies within sectors, we see a very large, significant and negative effect of repatriations on this variable. On average, in counties with one percent higher repatriation rate the share of low-skilled intensive sectors decreased by 0.35 percent. This implies that firms moved out and disappeared, likely reducing demand for natives employed in those sectors regardless of their skill level. As a consequence, low-skilled incumbent natives experienced a particularly large drop in demand, consistent with the negative employment results found above.

\subsection{County Level Regressions}

Are these effects on the incumbent native workers also discernible in aggregate outcomes? We now turn our attention to analyzing the effect of Mexican repatriations on aggregate local labor markets and not just on the incumbent natives. In addition to the impact on incumbents, these effects include the effects on in-migrating workers (newcomers) and exclude the consequences on out-migrating individuals (leavers). Moreover, the change in the local labor force composition driven by heterogeneity between those leaving, arriving and staying may affect the net change in employment and wages. The average effect on the local labor market is therefore a combination of several individual effects and a composition effect.

Table 10 presents the estimated coefficient of interest $\left(\beta_{2}\right)$ from equation 3. Note that unlike Tables 6-8, the unit of observation in these specifications is the county. Panel A presents the results for changes in employment between 1930 and 1940 as a share of 1930

\footnotetext{
${ }^{9}$ Notice that the dependent variable here is measured at the county level.
} 
population and in Panel B the outcome is the percent change in average occupational wage over the same time period. Columns 1 and 2 use our main IV, Columns 3 and 4 use the alternative IV and Columns 5 and 6 present the OLS estimates for comparison. The regressions in the odd-numbered columns use our baseline set of controls while the ones in the even-numbered columns control for the full set of covariates. Standard errors are clustered by state economic area and presented in parenthesis.

Consistent with Figure 3, the estimates in Panel A (Panel B) are positive but not statistically significant suggesting that the Mexican repatriation program did not result in employment (population) changes for natives at the county level. In particular, an increase in repatriation by one percent of the initial population was associated with an insignificant 0.2-0.6 (0.3-0.9) percent higher employment (population) for natives. The signs are reversed in the last two columns suggesting OLS estimates are biased in these aggregate regressions. Potential outflow of natives where repatriations efforts were more intense may be responsible for this bias. Given the negative employment results for incumbent native workers presented earlier, these overall null estimates suggest that in localities with more intense repatriation efforts native newcomers may have replaced some of the incumbents who, as we saw were more likely to loose their jobs. Panel $\mathrm{C}$ on the other hand shows that, as a result of the repatriation program, local labor markets experienced occupational downgrading stronger than shown in the individual level results. The estimates range between -0.8 to -1.2 in Columns 1 through 4 and they are statistically significant. On average, native workers took jobs that were significantly lower paid as a consequence of Mexican repatriations. This may certainly result from a selective internal migration due to the inflow of less qualified natives who took the jobs of the repatriated Mexicans.

Next, Table 11 breaks down the employment result by low- and high-skilled native workers in Panels A and B respectively. All coefficients in Panel A are positive and one is statistically significant. This suggests that, on aggregate, low-skilled local labor markets may have gained employment between 1930 and 1940 as a result of the repatriations. This is in contrast with 
the individual results on incumbents who experienced employment losses. In Panel B, highskilled natives show instead a decrease in aggregate employment, which is not statistically significant but the magnitude and sign of this effect are consistent with the one on highskilled incumbents. This aggregate effect is much less precisely estimated. The results in Table 11 imply that mobility of low-skilled natives into the area may have offset the impact on incumbents.

Overall, while the results using individual level data suggest detrimental labor market consequences for incumbent native workers, Tables 10 and 11 imply that, on aggregate, local labor market did not experience such negative effects. In other words, looking at the aggregate data masks the negative impacts on incumbent workers. How could these two results be reconciled? In next section we begin by exploring internal mobility of natives in response to Mexican repatriation as a potential factor driving this discrepancy. We then explain that by looking at aggregate labor market outcomes, we ignore outcomes for workers who out-migrate as a result of the supply shock and add the outcomes for newcomer natives.

\section{$7 \quad$ Reconciling Individual and Aggregate Effects}

To reconcile individual and local labor market level results, we examine whether the change in internal mobility of natives is consistent with the change in composition of working-age population in local labor markets. To do so we look at in- and out-migrations of natives. Notice that the effects on aggregate local labor markets combine the responses of three distinct groups. The first group is the incumbent workers who did not out-migrate to other areas. The second group includes in-migrated workers potentially attracted to replace jobs of repatriated Mexicans. Finally, the aggregate local effects do not include the group of leavers who out-migrate and are not observed in the county in 1940 (but were considered in the individual analysis of incumbents). We examine here the effects of repatriations on the number and the selection of in- and out-migrants. Higher repatriations attracted workers from 
outside to offset the loss of employment of incumbents generating null aggregate employment effects. Moreover, the selection of incomers in response to repatriation is negative and of leavers is positive on the occupational wage dimension which explains the larger aggregate wage downgrading relative to smaller individual downgrading.

\subsection{Internal Migration of Natives and Selection of Internal Mi- grants}

In Table 12, we first describe the outward mobility of incumbent natives in response to Mexican repatriation. We estimate equation (2) with the outcome being an indicator of migration status between 1930 and 1940 - equal to one if residing in a different county and zero otherwise. Panels A and B show the response of low and high-skilled natives respectively. Columns 1 and 2 present the 2SLS estimates using the main IV and Columns 3 and 4 report the estimates with the alternative IV. Finally, Columns 5 and 6 display the OLS estimates. Standard errors are presented in parenthesis and clustered by state economic area.

The repatriation of Mexicans resulted in significant out-migration of natives, both for low and high-skilled. Specifically, the 2SLS estimates suggest that a one percentage point increase in Mexican repatriation lowers the probability of incumbent low-skilled natives to live in the same county by 0.9-1.1 percentage points (Panel A). The out-migration effect was similar for high-skilled natives (Panel B). These are consistent with the detrimental labor market impact for incumbent native workers documented in Table 8. It is not clear, however, that these workers escaped the detrimental effects by outmigrating.

Next, we examine whether out-migration of native workers was replaced by in-migration of natives from other areas. We first assign individuals to the county in which they resided in 1940 (instead of in 1930). Then we construct a dummy variable indicating the in-migration from other counties between 1930 and 1940. We relate this outcome variable with our measure of Mexican repatriation. This regression examines whether there were inflows of natives associated to the repatriations. Namely, we analyze whether after the repatriation 
shock, the local population is more likely to have moved there from other counties, in a city with larger shocks compared to one with smaller shock. Table 13 presents the results for low-skilled (Panel A) and high-skilled (Panel B). The column order is the same as in the previous table.

We find higher although insignificant probability that low-skilled natives migrated to a county with larger Mexican repatriation in the 1930-40 relative to a city with lower repatriation rates. For each one percent larger Mexican migration, the probability that a low-skilled has migrated in the county is also one percent larger. On the other hand, the estimates are significantly lower for high-skilled natives. This is consistent with a story in which natives with similar skill level as Mexicans moved in counties with higher repatriation rates to look for jobs possibly left available as a consequence of the loss in Mexican labor force and from the fact that less skilled incumbent left or lost the jobs. The evidence seems consistent with Mexican repatriations generating some job vacancies that were not filled by incumbent native workers (who left or became non employed) but rather by workers who did not reside in these areas as of 1930. This may be because the specific occupation/skills of the incumbents did not match that of the departing Mexicans. On the other hand, for high-skilled natives, the effects were of increased outflows and no increased inflows.

This pattern of in-migration of low-skilled natives helps explain the discrepancies between the individual and local labor market levels results. In particular, the last regression show that there were inflows of low-skilled natives in response to the repatriation which may mask the decline in employment of low-skilled incumbents while for high-skilled the inflow was not significant consistent with similar individual and aggregate employment effects on this group. Selective inflows and outflows of natives in response to Mexicans' repatriations may also explain the much larger aggregate wage downgrading (Table 10) relative to the one experienced by incumbents (Table 7). To that end Table 14 shows how the occupational average wage of incomers (Panel A) or leavers (Panel B) is affected by the repatriation intensity of a County. The top panel shows a clear stronger negative selection of incomers 
in cities with large repatriations (negative and mostly significant coefficients), while the lower panel shows a neutral selection of leavers. Overall larger Mexican repatriations attract less skilled workers with lower occupational wages. This certainly contribute, through a composition effect, to the negative and large observed aggregate effect of Repatriation on occupational wages.

More generally, our results suggest that one should be cautious in interpreting analysis on labor supply shocks using aggregate labor market data. Such an aggregate analysis looses much nuance on winners and losers from a local shock. It may happen that incumbent lowskilled are hurt by a local shock, but on average low-skilled do not suffer as new arrivals and selective mobility change composition and generate an attenuated average outcome. Researchers should consider more carefully composition changes driven by the heterogeneous responses of incumbents and newcomers.

\subsection{Other Immigrants}

In the previous subsection we have analyzed the in- and out-migration of natives in response to Mexican Repatriation in a county. Here we further examine how the Mexican repatriation affected non-Mexican immigrants. In terms of their occupational distribution as of 1930 the non-Mexican immigrants resembled natives more than the Mexican workforce. Specifically, we estimate equation (3) using a sample of non-Mexican immigrants, instead of natives. We present the estimates in Table 15. Panel A shows the results for all other immigrants, and Panel B describes the responses of Southern Europeans who had relatively more similar skills to Mexicans. We report the 2SLS estimates using our main (Columns 1 and 2) and alternative (Columns 3 and 4) IVs. All regressions are weighted by 1930 population and standard errors are clustered by state economic area.

The results in Table 15 indicate that non-Mexican immigrants are not largely affected by the Mexican repatriation. While the estimates are negative in general, they are usually not statistically significant and the sizes of the coefficients are relatively small: a one percentage 
point larger Mexican repatriation lead to 0.01-0.09 percentage point decrease in non-Mexican immigrants. Just as incumbent natives, they experienced a negative, albeit quite small, employment effect as a result of the Mexican repatriations. Overall, we do not find evidence that, on aggregate, the repatriation program helped employment of non-Mexican foreignborn.

\subsection{Discussion}

Collectively considering our the individual and aggregate results, two tendencies appear rather clear and yet require some reconciliation. First, Mexican repatriations are associated with a significant decline in employment probability of natives $(-0.2$ percent for an increase of repatriations by one percent of the population) who lived, as of 1930 in the county where Mexican left. This effect is particularly strong for low-skilled natives (-0.5). However, in aggregate we find no significant effect on change in local native employment. Let us emphasize that on average only about $60 \%$ of people did not change county between 1930 and 1940 . Hence, the inflow of newcomers may significantly alter the aggregate local effect relative to the effect on incumbents.

In Tables 12 and 13 we also see that Mexican repatriations encouraged both outflow (significantly) and inflow (not significantly) of low-skilled natives in the county. This likely changed the local composition, so that if newcomers took low-skilled manual jobs at higher rate than incumbents, they may have balanced the aggregate employment. The -0.2 decline in employment probability of incumbents need to be scaled (multiplied) by $60 \%$ to have the aggregate effect (-0.12 on the average person). The increased inflow and outflow of natives likely masked this effect. A second hint that the selection of newcomers may help explain the discrepancies between individual and aggregate effects is in Table 14. There, we observe a significant negative selection of newcomers relative to incumbents in terms of occupational wages. If the inflow of newcomers was concentrated among employed low-skilled, this explains the offset of the negative effect on incumbents, as well as the larger decline in occupational 
wages observed in aggregate $(-0.9$, in Table 10$)$ relative to the decline on individual wages of incumbents (-0.3). Moreover, a look at Tables 12 and 13 shows that high-skilled natives experienced larger outflows but not larger inflows in response to Mexican repatriations, also confirming the possibility of a deterioration of the native skills in response. So the evidence for Mexican repatriation effects on mobility and selection is very important as it suggests that aggregate numbers are very imprecise measure of the effect on wages of incumbents. Composition effect in response to immigration are likely to pollute substantially the analysis of cleaner employment/productivity effect of the repatriation of Mexicans. We therefore emphasize the importance of our individual data analysis to identify such effects.

\section{Conclusion}

This is one of the very few studies focusing on the economic effects of the immigrant repatriation. We analyze a large scale repatriation campaign enacted in the US between 1929 and 1934 against people of Mexican origin. Politicians at that time argued that it would give jobs to American workers and attenuate the unemployment problems caused by the Great Depression. They were certain that the removal of Mexicans would improve the employment prospects for the jobless natives and raise their wages. It is difficult to think of another period in US history when the prevalence of unemployed American workers was larger and the repatriation effects should have been stronger. In this paper we use linked individual level and county level data from full count 1930 and 1940 censuses to analyze whether these strong claims had any validity.

From the individual level linked regressions, we find that the Mexican repatriation program reduced the employment opportunities of incumbent natives. It also generated significant occupational downgrading of native workers as well as an out-migration response. This finding is robust across several different specifications and subsamples. Furthermore, from the aggregate labor market data, we also find that there were significant changes in the 
composition of native workers within the labor market due to associated selective in- and out-migration. This compositional change of the local population of natives masked the negative impacts on employment of incumbent workers. These results suggest that researchers should use caution when analyzing aggregate and repeated cross sectional data to identify the productivity and employment effect of natives on incumbent natives.

Overall, not only did politicians' claims not materialize, but it seems like the repatriation program may have hurt some native workers. Specifically, the repatriation of Mexicans, who were mostly laborers and farm workers, reduced demand for other jobs in the local economy mainly held by natives. This was partly because of the complementarity between Mexicans and natives and the fact that specific local factors (such as entrepreneurship) in Mexicanintensive sectors shrunk as Mexicans left. The repatriation of Mexicans did not even result in other immigrants gaining jobs. This campaign caused pain, disruption and suffering for Mexicans, but did not deliver any of the labor market benefits promised to natives. 


\section{References}

Abramitzky, Ran, Leah Boustan, and Katherine Eriksson, "To the new world and back again: Return migrants in the age of mass migration," ILR Review, 2019, 72 (2), $300-322$.

_, Leah Platt Boustan, and Katherine Eriksson, "Europe's tired, poor, huddled masses: Self-selection and economic outcomes in the age of mass migration," American Economic Review, 2012, 102 (5), 1832-56.

_, _, and _, "A nation of immigrants: Assimilation and economic outcomes in the age of mass migration," Journal of Political Economy, 2014, 122 (3), 467-506.

Balderrama, Francisco E and Raymond Rodríguez, Decade of betrayal: Mexican repatriation in the 1930s, UNM Press, 2006.

Bartik, Timothy J, "Who benefits from state and local economic development policies?," 1991.

Borjas, George J, "The wage impact of the Marielitos: A reappraisal," ILR Review, 2017, 70 (5), 1077-1110.

- and Lawrence F Katz, "The evolution of the Mexican-born workforce in the United States," in "Mexican immigration to the United States" University of Chicago Press 2007, pp. $13-56$.

Boustan, Leah Platt, Price V Fishback, and Shawn Kantor, "The effect of internal migration on local labor markets: American cities during the Great Depression," Journal of Labor Economics, 2010, 28 (4), 719-746.

Card, David, "The impact of the Mariel boatlift on the Miami labor market," ILR Review, 1990, $43(2), 245-257$.

_ , "Immigrant inflows, native outflows, and the local labor market impacts of higher immigration," Journal of Labor Economics, 2001, 19 (1), 22-64.

_ , "Is the new immigration really so bad?," The Economic Journal, 2005, 115 (507), F300F323.

_ and Ethan G Lewis, "The diffusion of Mexican immigrants during the 1990s: Explanations and impacts," in "Mexican immigration to the United States" University of Chicago Press 2007, pp. 193-228.

Clemens, Michael A, Ethan G Lewis, and Hannah M Postel, "Immigration restrictions as active labor market policy: Evidence from the mexican bracero exclusion," American Economic Review, 2018, 108 (6), 1468-87.

Commercial Atlas of the World

Commercial Atlas of the World, Geographical Publishing Company, 1931. 
Fishback, Price V, William C Horrace, and Shawn Kantor, "Did New Deal grant programs stimulate local economies? A study of Federal grants and retail sales during the Great Depression," The Journal of Economic History, 2005, 65 (1), 36-71.

Foged, Mette and Giovanni Peri, "Immigrants' effect on native workers: New analysis on longitudinal data," American Economic Journal: Applied Economics, 2016, 8 (2), 1-34.

Goldin, Claudia Dale and Lawrence F Katz, The race between education and technology, harvard university press, 2009.

Gratton, Brian and Emily Merchant, "Immigration, repatriation, and deportation: The Mexican-origin population in the United States, 1920-1950," International Migration Review, 2013, 47 (4), 944-975.

Hoffman, Abraham, "Mexican Repatriation Statistics: Some Suggested Alternatives to Carey McWilliams," The Western Historical Quarterly, 1972, 3 (4), 391-404.

Hong, Gihoon and John McLaren, "Are Immigrants a Shot in the Arm for the Local Economy?," Technical Report, National Bureau of Economic Research 2015.

Jaeger, David A, Joakim Ruist, and Jan Stuhler, "Shift-share instruments and the impact of immigration," Technical Report, National Bureau of Economic Research 2018.

Johnson, Kevin R, "The forgotten repatriation of persons of Mexican ancestry and lessons for the war on terror," PACe l. rev., 2005, 26, 1.

Kerr, William R and William F Lincoln, "The supply side of innovation: H-1B visa reforms and US ethnic invention," Journal of Labor Economics, 2010, 28 (3), 473-508.

Lewis, Ethan, "Immigration, skill mix, and capital skill complementarity," The Quarterly Journal of Economics, 2011, 126 (2), 1029-1069.

_, "Immigration and production technology," Annu. Rev. Econ., 2013, 5 (1), 165-191.

Monras, Joan, "Immigration and wage dynamics: Evidence from the mexican peso crisis," 2018.

Ottaviano, Gianmarco IP and Giovanni Peri, "Rethinking the effect of immigration on wages," Journal of the European economic association, 2012, 10 (1), 152-197.

Peri, Giovanni and Chad Sparber, "Task specialization, immigration, and wages," American Economic Journal: Applied Economics, 2009, 1 (3), 135-69.

- and Vasil Yasenov, "The Labor Market Effects of a Refugee Wave Synthetic Control Method Meets the Mariel Boatlift," Journal of Human Resources, 2019, 54 (2), 267-309.

_, Kevin Shih, and Chad Sparber, "STEM workers, H-1B visas, and productivity in US cities," Journal of Labor Economics, 2015, 33 (S1), S225-S255. 
Ruggles, Steven, Sarah Flood, Ronald Goeken, Josiah Grover, Erin Meyer, Jose Pacas, and Matthew Sobek, "Integrated public use microdata series: Version 9.0 [dataset]," Minneapolis: University of Minnesota, 2019, 23, 56.

Simon, Daniel T, "Mexican Repatriation in East Chicago, Indiana," The Journal of Ethnic Studies, 1974, 2 (2), 11. 


\section{Figures and Tables}

Figure 1: Mexican Repatriation Intensity, 1930-40

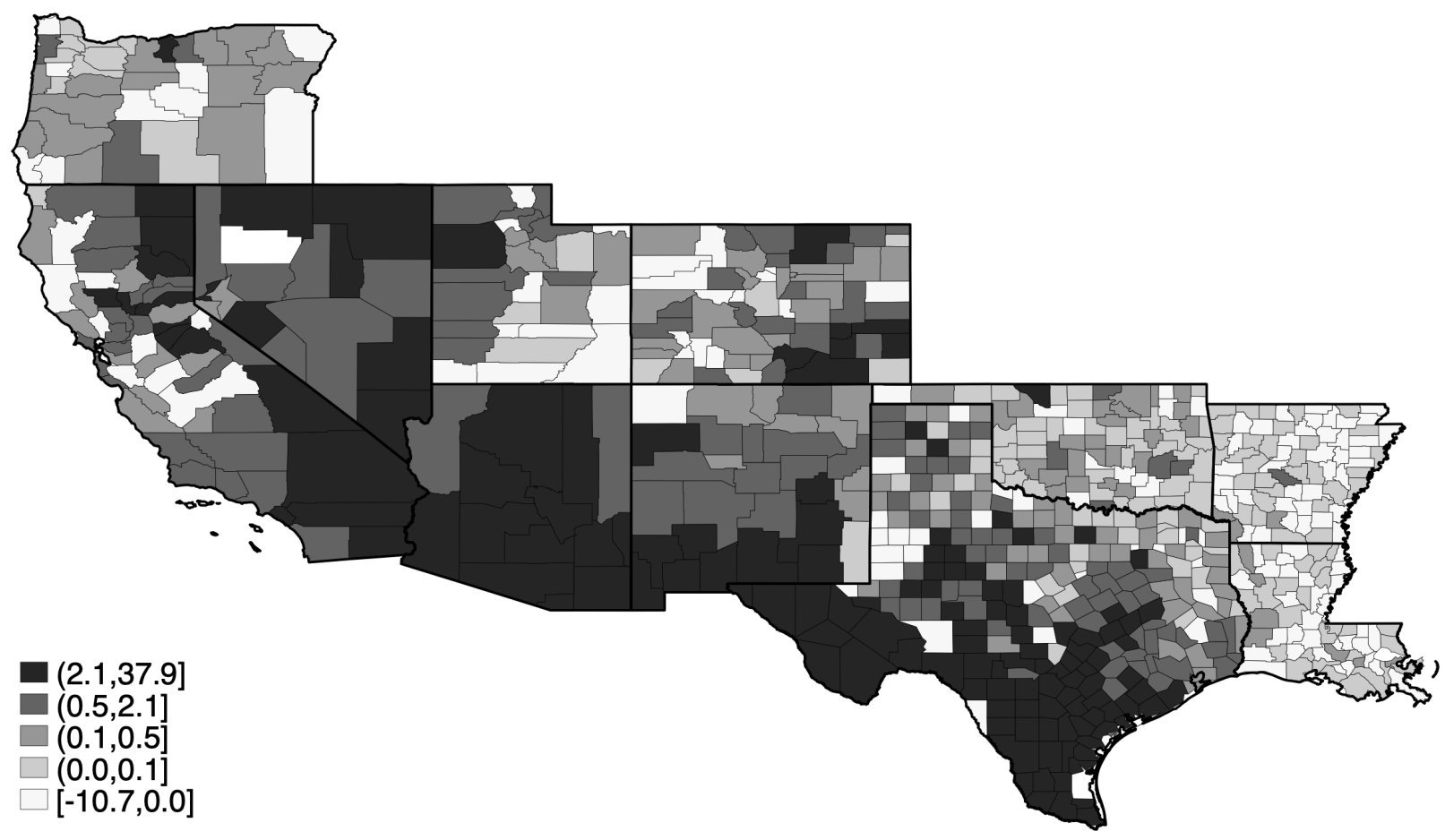

Notes: Each polygon is a separate US county and shows the 1940-1930 change in working age Mexican population as a share of the total working age population in 1930. Darker shades of gray correspond to higher repatriation rate. Sources: the 1930 and 1940 US censuses (Ruggles et al., 2019). 
Figure 2: Major Railroads to Mexico and Size of Pre-existing Mexican Community

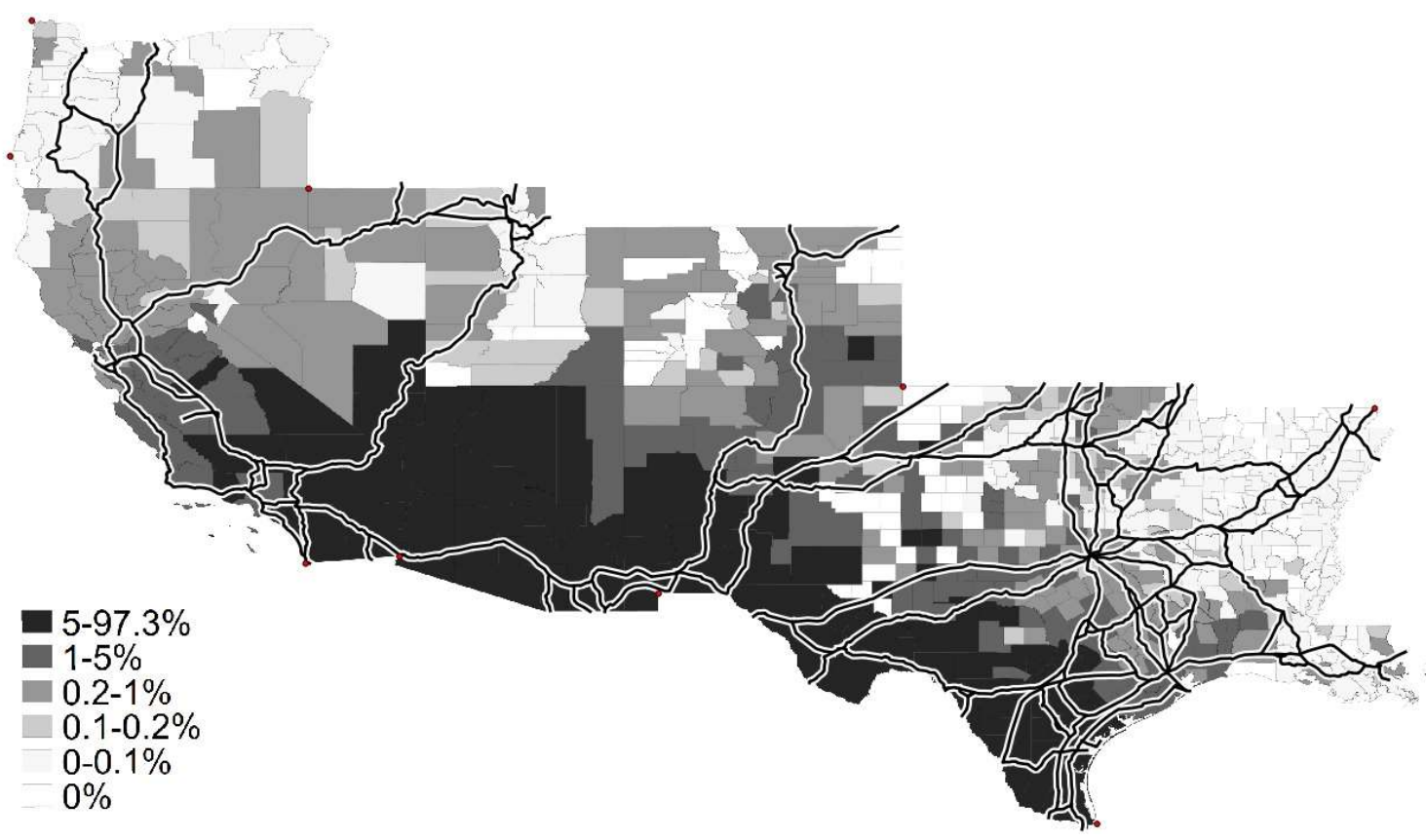

Notes: Each polygon is a separate US county and shows the share of working age Mexicans in the total working age population in 1910. Darker shades of gray denote higher values. The black and white lines correspond to major railroads to Mexico as of 1931. Sources: the 1910 US census (Ruggles et al., 2019) and the Commercial Atlas of the World (1931). 
Figure 3: Correlation between Mexican Repatriation and Natives' Labor Market Outcomes

\section{Panel A: Employment}
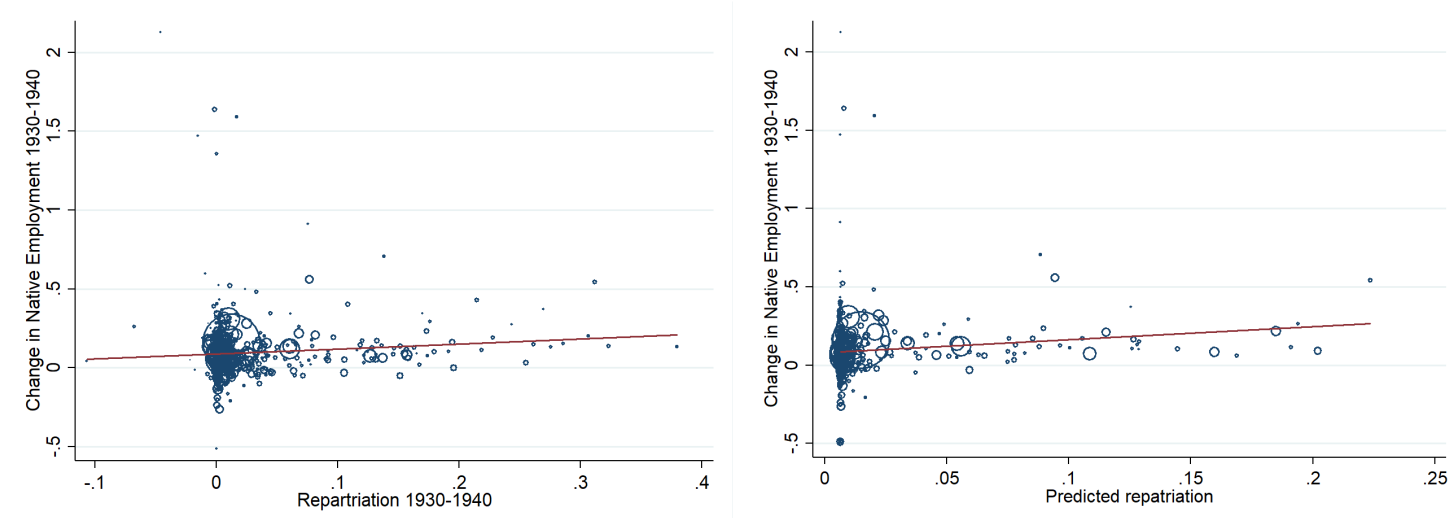

Panel B: Population
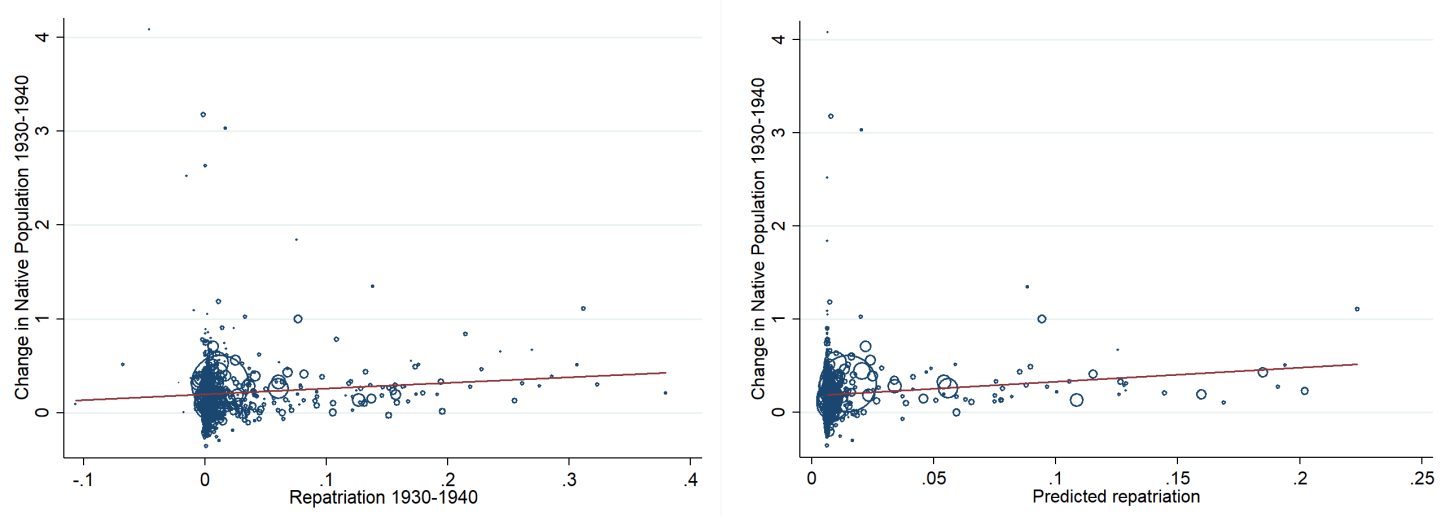

Panel C: Occupational Wage
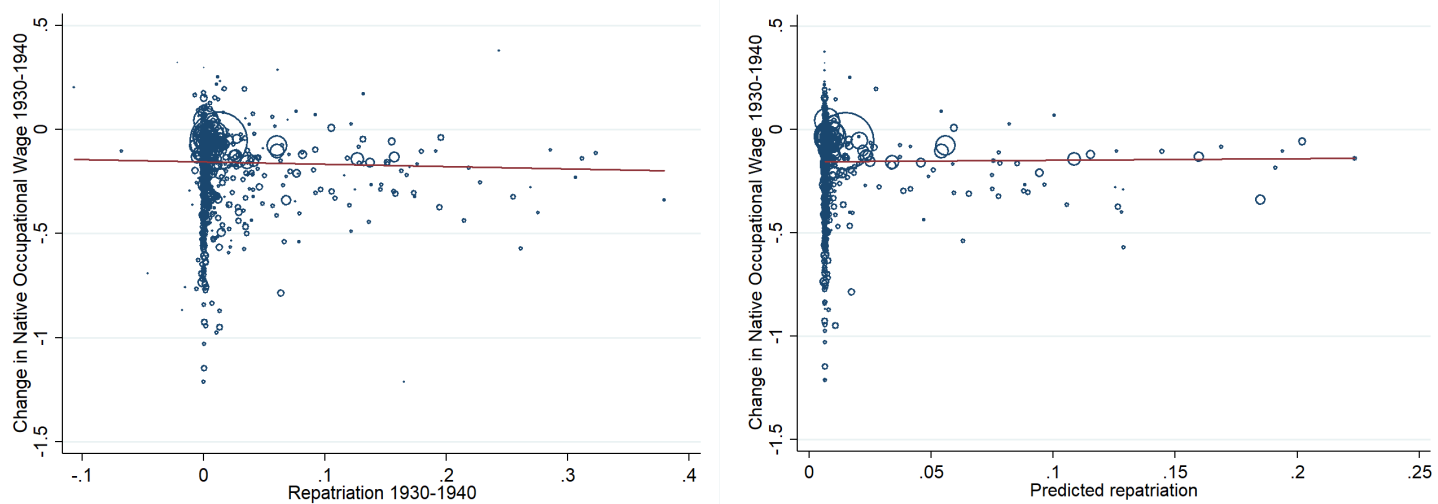

Notes: Scatter plots of the 1930-40 change in working age Mexican population (left figures) or our main instrumental variable (right figures) on an outcome variable denoted in the $\mathrm{y}$-axis in each panel. Each circle is a separate county and its size is proportional to the corresponding 1930 working age population. 
Table 1: Occupational Distribution in 1930 by Ethnicity

\begin{tabular}{lccc}
\hline & $\begin{array}{c}\text { Mexican, } \\
\text { Full Count } \\
\text { Data } \\
(1)\end{array}$ & $\begin{array}{c}\text { Native, } \\
\text { Full Count } \\
\text { Data } \\
(2)\end{array}$ & $\begin{array}{c}\text { Native, } \\
\text { Linked Individuals } \\
\text { Data } \\
(3)\end{array}$ \\
\hline \multicolumn{1}{c}{ High-Skilled Occupations } & & & \\
Managers, Officials, and Proprietors & 3 & 9 & 12 \\
Professional and Technical & 1 & 9 & 7 \\
Craftsmen & 7 & 13 & 20 \\
Sales workers & 3 & 10 & 11 \\
Clerical & 2 & 10 & 7 \\
and Kindred & & & 14 \\
Operatives & 11 & 11 & 14 \\
\hline \multicolumn{1}{c}{ Low-Skilled Occupations } & & & 10 \\
Service workers & 11 & 13 & 5 \\
Laborers & & 11 & \\
Farm laborers & 29 & 14 & \\
\hline
\end{tabular}

Notes: Each column shows the percent workers from the specified ethnicity in various occupation categories in 1930. The last column presents the statistics for the linked individuals data. The occupations groups are ordered by mean wage in 1940. All numbers are rounded to the nearest integer. Source: the 1930 US census. 
Table 2: Descriptive Statistics

\begin{tabular}{|c|c|c|c|}
\hline & \multicolumn{3}{|c|}{ Panel A: Individual Level } \\
\hline & $\begin{array}{c}\text { Full Count Data, } \\
\text { Everyone } \\
(1)\end{array}$ & $\begin{array}{c}\text { Full Count Data, } \\
\text { Men Only } \\
(2)\end{array}$ & $\begin{array}{c}\text { Linked } \\
\text { Individuals Data } \\
(3)\end{array}$ \\
\hline & \multicolumn{3}{|c|}{ Entire Sample } \\
\hline Age & 33.580 & 33.840 & 33.237 \\
\hline Male & 0.504 & 1.00 & 1.00 \\
\hline Black & 0.128 & 0.124 & 0.085 \\
\hline Married & 0.683 & 0.648 & 0.666 \\
\hline Literate & 0.956 & 0.954 & 0.974 \\
\hline In School & 0.053 & 0.055 & 0.062 \\
\hline In Labor Force & 0.599 & 0.929 & 0.932 \\
\hline \multirow[t]{2}{*}{ Observations } & $10,128,862$ & $5,102,938$ & $1,475,002$ \\
\hline & \multicolumn{3}{|c|}{ Employed Sample } \\
\hline Low-Skilled & 0.376 & 0.368 & 0.338 \\
\hline High-Skilled & 0.624 & 0.632 & 0.662 \\
\hline Wage & 3.229 & 3.305 & 3.497 \\
\hline \multirow[t]{3}{*}{ Observations } & $3,501,312$ & $2,575,668$ & 712,019 \\
\hline & \multicolumn{3}{|c|}{ Panel B: Labor Market Level } \\
\hline & Mean & Min & $\operatorname{Max}$ \\
\hline Mexican Repatriation & 0.018 & -0.107 & 0.326 \\
\hline Population & $18,435.87$ & 137 & $1,505,330$ \\
\hline Share illiterate & 0.070 & 0 & 0.537 \\
\hline Aged 18 to 40 & 0.640 & 0.392 & 0.814 \\
\hline Percent farm land & 0.552 & 0 & 1.466 \\
\hline Median Occ. Wage & 3.965 & 2.775 & 4.821 \\
\hline Retail sales growth & -0.542 & -1.670 & 1.019 \\
\hline Log New Deal Spending & 14.566 & 10.566 & 19.583 \\
\hline Months of extreme weather & 8.095 & 0 & 82 \\
\hline Intensity of Dust Bowl & 0.188 & 0 & 5 \\
\hline Distance to Mexico (miles) & 430.94 & 0.444 & $1,019.44$ \\
\hline Railway dummy & 0.468 & 0 & 1 \\
\hline Share of Mexicans 1910 & 0.041 & 0 & 0.973 \\
\hline Bartik index & -0.028 & -0.200 & 0.176 \\
\hline Observations & & 686 & \\
\hline
\end{tabular}

Notes: Panel A shows variable means of the individual level 1930 full count census data (columns 1 and 2) and the 1930-40 linked individuals census data (column 3). Panel B presents summary statistics for our county level variables in 1930 . 
Table 3: First Stage Regressions

\begin{tabular}{lcccc}
\hline \hline & $(1)$ & $(2)$ & $(3)$ & $(4)$ \\
\hline Main IV & & & & \\
& $0.166^{* * *}$ & $0.165^{* * *}$ & & \\
Alternative IV & $(0.038)$ & $(0.037)$ & & \\
& & & $0.136^{* * *}$ & $0.134^{* * *}$ \\
& & & $(0.034)$ & $(0.034)$ \\
1st stage $F$ & 19.40 & 19.56 & 15.48 & 15.67 \\
Observations & 686 & 684 & 686 & 684 \\
R-squared & 0.633 & 0.635 & 0.593 & 0.596 \\
Baseline Controls & $\mathrm{X}$ & & $\mathrm{X}$ & \\
Full Controls & & $\mathrm{X}$ & & $\mathrm{X}$ \\
State FE & $\mathrm{X}$ & $\mathrm{X}$ & $\mathrm{X}$ & $\mathrm{X}$ \\
Weighted & $\mathrm{X}$ & $\mathrm{X}$ & $\mathrm{X}$ & $\mathrm{X}$ \\
\hline \hline
\end{tabular}

Notes: Each entry shows the estimated coefficient from a regression of the change in Mexican working age population between 1930 and 1940 relative to total working age population in 1930 on our instrumental variable and a set of controls. The unit of observation is a county. The sample consists of non-Mexican natives age 18-65, in the labor force, not employed in the army, not an unpaid family worker and not attending school. Baseline controls include log of working age population, the Bartik index, the percent of farm land, median occupational wage, distance to Mexico, presence of a railway to Mexico, share of police, aged 18 to 40, and illiterate. Full controls further include retail sales growth, log of New Deal spending, intensity of the Dust Bowl, and the number of months of extreme whether. All regressions are weighted by total working age population in 1930. Standard errors are clustered by state economic area.

${ }^{* * *} \mathrm{p}<0.01,{ }^{* *} \mathrm{p}<0.05,{ }^{*} \mathrm{p}<0.1$ 
Table 4: Instrumental Variable Falsification Tests

\begin{tabular}{|c|c|c|c|c|}
\hline & \multicolumn{4}{|c|}{ Panel A: $\Delta$ Employment 1910-1930 } \\
\hline & $(1)$ & $(2)$ & $(3)$ & $(4)$ \\
\hline Main IV & $\begin{array}{l}-0.276 \\
(0.502)\end{array}$ & $\begin{array}{l}-0.207 \\
(0.423)\end{array}$ & & \\
\hline Alternative IV & & & $\begin{array}{l}-0.398 \\
(0.526)\end{array}$ & $\begin{array}{l}-0.358 \\
(0.451)\end{array}$ \\
\hline \multirow[t]{3}{*}{$\begin{array}{l}\text { Observations } \\
\text { R-squared }\end{array}$} & $\begin{array}{c}686 \\
0.230\end{array}$ & $\begin{array}{c}684 \\
0.253\end{array}$ & $\begin{array}{c}686 \\
0.230\end{array}$ & $\begin{array}{c}684 \\
0.253\end{array}$ \\
\hline & \multicolumn{4}{|c|}{ Panel B: $\Delta$ Population 1920-1930 } \\
\hline & $(1)$ & $(2)$ & $(3)$ & $(4)$ \\
\hline Main IV & $\begin{array}{l}-1.528 \\
(1.174)\end{array}$ & $\begin{array}{l}-1.708 \\
(1.291)\end{array}$ & & \\
\hline Alternative IV & & & $\begin{array}{l}-1.717 \\
(1.285)\end{array}$ & $\begin{array}{l}-1.941 \\
(1.418)\end{array}$ \\
\hline \multirow[t]{3}{*}{$\begin{array}{l}\text { Observations } \\
\text { R-squared }\end{array}$} & $\begin{array}{c}686 \\
0.098\end{array}$ & $\begin{array}{c}684 \\
0.109\end{array}$ & $\begin{array}{c}686 \\
0.098\end{array}$ & $\begin{array}{c}684 \\
0.109\end{array}$ \\
\hline & \multicolumn{4}{|c|}{ Panel C: $\Delta$ Occupational Wage 1910-1930 } \\
\hline & $(1)$ & $(2)$ & $(3)$ & $(4)$ \\
\hline Main IV & $\begin{array}{c}0.030 \\
(0.100)\end{array}$ & $\begin{array}{c}0.041 \\
(0.098)\end{array}$ & & \\
\hline Alternative IV & & & $\begin{array}{c}0.084 \\
(0.092)\end{array}$ & $\begin{array}{c}0.094 \\
(0.090)\end{array}$ \\
\hline \multirow[t]{3}{*}{$\begin{array}{l}\text { Observations } \\
\text { R-squared }\end{array}$} & $\begin{array}{c}686 \\
0.652\end{array}$ & $\begin{array}{c}684 \\
0.655\end{array}$ & $\begin{array}{c}686 \\
0.653\end{array}$ & $\begin{array}{c}684 \\
0.656\end{array}$ \\
\hline & \multicolumn{4}{|c|}{ Panel D: Moved Within State 1920-1930 } \\
\hline & $(1)$ & $(2)$ & $(3)$ & $(4)$ \\
\hline Main IV & $\begin{array}{l}-0.025 \\
(0.063)\end{array}$ & $\begin{array}{l}-0.036 \\
(0.063)\end{array}$ & & \\
\hline Alternative IV & & & $\begin{array}{l}-0.034 \\
(0.066)\end{array}$ & $\begin{array}{c}-0.041 \\
(0.066)\end{array}$ \\
\hline \multirow[t]{3}{*}{$\begin{array}{l}\text { Observations } \\
\text { Adjusted } R^{2}\end{array}$} & $\begin{array}{c}1393882 \\
0.052\end{array}$ & $\begin{array}{c}1393792 \\
0.053\end{array}$ & $\begin{array}{c}1393882 \\
0.052\end{array}$ & $\begin{array}{c}1393792 \\
0.053\end{array}$ \\
\hline & \multicolumn{4}{|c|}{ Panel E: Same County 1920-1930 } \\
\hline & (1) & $(2)$ & $(3)$ & $(4)$ \\
\hline Main IV & $\begin{array}{c}-0.147^{*} \\
(0.082)\end{array}$ & $\begin{array}{c}-0.145^{*} \\
(0.080)\end{array}$ & & \\
\hline Alternative IV & & & $\begin{array}{l}-0.131 \\
(0.087)\end{array}$ & $\begin{array}{l}-0.124 \\
(0.084)\end{array}$ \\
\hline $\begin{array}{l}\text { Observations } \\
\text { Adjusted } R^{2}\end{array}$ & $\begin{array}{c}1393882 \\
0.050\end{array}$ & $\begin{array}{c}1393792 \\
0.051\end{array}$ & $\begin{array}{c}1393882 \\
0.050\end{array}$ & $\begin{array}{c}1393792 \\
0.051\end{array}$ \\
\hline $\begin{array}{l}\text { Baseline Controls } \\
\text { Full Controls } \\
\text { State FE } \\
\text { Weighted }\end{array}$ & $\begin{array}{l}X \\
X \\
X\end{array}$ & $\begin{array}{l}\mathrm{X} \\
\mathrm{X} \\
\mathrm{X}\end{array}$ & $\begin{array}{l}X \\
X \\
X\end{array}$ & $\begin{array}{l}\mathrm{X} \\
\mathrm{X} \\
\mathrm{X}\end{array}$ \\
\hline
\end{tabular}

Notes: Each entry shows the estimated coefficient from a regression of a pre-trend variable denoted in each panel header on our instrumental variable and a set of controls. The unit of observation is a county in Panels A-C and an individual worker in Panels D-E. The sample consists of non-Mexican natives age 18-65, in the labor force, not employed in the army, not an unpaid family worker and not attending school. Baseline and full controls are defined as in Table 3. All regressions are weighted by total working age population in 1930. Standard errors are clustered by state economic area.

${ }^{* * *} \mathrm{p}<0.01,{ }^{* *} \mathrm{p}<0.05,{ }^{*} \mathrm{p}<0.1$ 
Table 5: Correlation between the Instruments and the Share of Linked Individuals

\begin{tabular}{lcccc}
\hline \hline & \multicolumn{4}{c}{ Outcome: Share linked individuals } \\
\cline { 2 - 5 } & $(1)$ & $(2)$ & $(3)$ & $(4)$ \\
\hline & & & & \\
Main IV & 0.001 & -0.005 & & \\
& $(0.018)$ & $(0.018)$ & & \\
Alternative IV & & & -0.008 & -0.012 \\
& & & $(0.017)$ & $(0.017)$ \\
& & & & \\
\hline Observations & 686 & 684 & 686 & 684 \\
R-squared & 0.839 & 0.840 & 0.839 & 0.840 \\
Baseline Controls & $\mathrm{X}$ & & $\mathrm{X}$ & \\
Full Controls & & $\mathrm{X}$ & & $\mathrm{X}$ \\
State FE & $\mathrm{X}$ & $\mathrm{X}$ & $\mathrm{X}$ & $\mathrm{X}$ \\
Weighted & $\mathrm{X}$ & $\mathrm{X}$ & $\mathrm{X}$ & $\mathrm{X}$ \\
\hline \hline
\end{tabular}

Notes: Each entry shows the estimated coefficient from a regression of the share of linked individuals on our instrumental variable and a set of controls. The unit of observation is a county. The sample consists of non-Mexican natives age 18-65, in the labor force, not employed in the army, not an unpaid family worker and not attending school. Baseline and full controls are defined as in Table 3. All regressions are weighted by total working age population in 1930. Standard errors are clustered by state economic area.

$* * * \mathrm{p}<0.01,{ }^{* *} \mathrm{p}<0.05,{ }^{*} \mathrm{p}<0.1$ 
Table 6: The Impact of Mexican Repatriation on Employment: Individual Level Results

\begin{tabular}{|c|c|c|c|c|c|c|}
\hline & \multicolumn{6}{|c|}{ Panel A: $\Delta$ Employment 1930-1940 } \\
\hline & (1) & $(2)$ & $(3)$ & $(4)$ & $(5)$ & (6) \\
\hline \multirow{2}{*}{ Repatriation $_{c}$} & $-0.207^{* *}$ & $-0.219^{* *}$ & $-0.239^{* *}$ & $-0.254^{* * *}$ & $-0.133^{*}$ & $-0.139^{*}$ \\
\hline & $(0.078)$ & $(0.084)$ & $(0.092)$ & $(0.095)$ & $(0.078)$ & $(0.064)$ \\
\hline Observations & $1,281,290$ & $1,281,267$ & $1,281,290$ & $1,281,267$ & $1,281,290$ & $1,281,267$ \\
\hline \multirow[t]{3}{*}{ Adjusted $R^{2}$} & 0.018 & 0.018 & 0.018 & 0.018 & 0.019 & 0.019 \\
\hline & \multicolumn{6}{|c|}{ Panel B: Non-Employed $1930 \rightarrow$ Employed 1940} \\
\hline & (1) & $(2)$ & $(3)$ & (4) & (5) & (6) \\
\hline \multirow{2}{*}{ Repatriation $_{c}$} & $-0.238^{* * *}$ & $-0.242^{* * *}$ & $-0.288^{* * *}$ & $-0.292^{* * *}$ & $-0.107^{* * *}$ & $-0.114^{* * *}$ \\
\hline & $(0.067)$ & $(0.066)$ & $(0.071)$ & $(0.070)$ & $(0.037)$ & $(0.037)$ \\
\hline Observations & $1,281,290$ & $1,281,267$ & $1,281,290$ & $1,281,267$ & $1,281,290$ & $1,281,267$ \\
\hline \multirow[t]{3}{*}{ Adjusted $R^{2}$} & 0.009 & 0.009 & 0.009 & 0.009 & 0.010 & 0.010 \\
\hline & \multicolumn{6}{|c|}{ Panel C: Employed $1930 \rightarrow$ Non-Employed 1940} \\
\hline & (1) & $(2)$ & $(3)$ & (4) & $(5)$ & (6) \\
\hline \multirow{2}{*}{ Repatriation $_{c}$} & -0.049 & -0.041 & -0.059 & -0.050 & -0.015 & -0.016 \\
\hline & $(0.048)$ & $(0.049)$ & $(0.054)$ & $(0.056)$ & $(0.024)$ & $(0.024)$ \\
\hline Observations & $1,281,290$ & $1,281,267$ & $1,281,290$ & $1,281,267$ & $1,281,290$ & $1,281,267$ \\
\hline \multirow[t]{3}{*}{ Adjusted $R^{2}$} & 0.002 & 0.002 & 0.002 & 0.002 & 0.002 & 0.002 \\
\hline & \multicolumn{6}{|c|}{ Panel D: $\Delta$ Self-Employment 1930-1940 } \\
\hline & (1) & $(2)$ & $(3)$ & (4) & (5) & (6) \\
\hline \multirow{2}{*}{ Repatriation $_{c}$} & -0.088 & -0.094 & -0.263 & -0.269 & 0.024 & 0.031 \\
\hline & $(0.242)$ & $(0.238)$ & $(0.246)$ & $(0.241)$ & $(0.159)$ & $(0.160)$ \\
\hline Observations & $1,281,290$ & $1,281,267$ & $1,281,290$ & $1,281,267$ & $1,281,290$ & $1,281,267$ \\
\hline Adjusted $R^{2}$ & 0.014 & 0.014 & 0.014 & 0.014 & 0.019 & 0.019 \\
\hline 1st Stage $F$ & 26.360 & 27.368 & 22.567 & 23.575 & - & - \\
\hline Baseline Controls & $\mathrm{X}$ & & $\mathrm{X}$ & & $\mathrm{X}$ & \\
\hline Full Controls & & $\mathrm{X}$ & & $\mathrm{X}$ & & $\mathrm{X}$ \\
\hline Main IV & $\mathrm{X}$ & $\mathrm{X}$ & & & & \\
\hline Alternative IV & & & $\mathrm{X}$ & $\mathrm{X}$ & & \\
\hline OLS & & & & & $\mathrm{X}$ & $\mathrm{X}$ \\
\hline
\end{tabular}

Notes: Each entry shows the estimated coefficient from a regression of a labor market outcome denoted in each panel header on the change in Mexican working age population between 1930 and 1940 relative to total working age population in 1930 and a set of controls. The unit of observation is an individual worker. The sample consists of non-Mexican natives age 18-55, in the labor force, not employed in the army, not an unpaid family worker and not attending school, all in 1930. All regressions control for age, race and marriage and literacy indicators. In addition, baseline and full controls are defined as in Table 3 . ${ }^{* * *} \mathrm{p}<0.01,{ }^{* *} \mathrm{p}<0.05,{ }^{*} \mathrm{p}<0.1$ 
Table 7: The Impact of Mexican Repatriation on Occupational Standing: Individual Level Results

\begin{tabular}{|c|c|c|c|c|c|c|}
\hline & \multicolumn{6}{|c|}{ Panel A: $\Delta$ Occupational Wage 1930-1940 } \\
\hline & (1) & $(2)$ & $(3)$ & (4) & (5) & (6) \\
\hline \multirow[t]{2}{*}{ Repatriation $_{c}$} & -0.338 & -0.359 & $-0.674^{*}$ & $-0.713^{*}$ & -0.220 & -0.192 \\
\hline & $(0.398)$ & $(0.409)$ & $(0.398)$ & $(0.415)$ & $(0.264)$ & $(0.261)$ \\
\hline Observations & 996,994 & 996,976 & 996,994 & 996,976 & 996,994 & 996,976 \\
\hline \multirow[t]{3}{*}{ Adjusted $R^{2}$} & 0.035 & 0.036 & 0.035 & 0.036 & 0.046 & 0.046 \\
\hline & \multicolumn{6}{|c|}{ Panel B: $\Delta$ Occupational Score 1930-1940 } \\
\hline & (1) & $(2)$ & $(3)$ & (4) & (5) & (6) \\
\hline \multirow[t]{2}{*}{ Repatriation $_{c}$} & -0.145 & -0.105 & $-0.188^{*}$ & -0.150 & $-0.193^{* * *}$ & $-0.194^{* * *}$ \\
\hline & $(0.109)$ & $(0.113)$ & $(0.127)$ & $(0.130)$ & $(0.059)$ & $(0.054)$ \\
\hline Observations & $1,002,467$ & $1,002,449$ & $1,002,467$ & $1,002,449$ & $1,00,2467$ & $1,002,449$ \\
\hline Adjusted $R^{2}$ & 0.029 & 0.029 & 0.029 & 0.029 & 0.031 & 0.031 \\
\hline 1st Stage $F$ & 26.715 & 27.783 & 23.320 & 24.382 & - & - \\
\hline Baseline Controls & $\mathrm{X}$ & & $\mathrm{X}$ & & $\mathrm{X}$ & \\
\hline Full Controls & & $\mathrm{X}$ & & $\mathrm{X}$ & & $\mathrm{X}$ \\
\hline Main IV & $\mathrm{X}$ & $\mathrm{X}$ & & & & \\
\hline Alternative IV & & & $\mathrm{X}$ & $\mathrm{X}$ & & \\
\hline OLS & & & & & $\mathrm{X}$ & $\mathrm{X}$ \\
\hline
\end{tabular}

Notes: Each entry shows the estimated coefficient from a regression of a labor market outcome denoted in each panel header on the change in Mexican working age population between 1930 and 1940 relative to total working age population in 1930 and a set of controls. The unit of observation is an individual worker. The sample consists of non-Mexican natives age 18-55, in the labor force, not employed in the army, not an unpaid family worker and not attending school, all in 1930. All regressions control for age, race and marriage and literacy indicators. In addition, baseline and full controls are defined as in Table 3 . ${ }^{* * *} \mathrm{p}<0.01,{ }^{* *} \mathrm{p}<0.05,{ }^{*} \mathrm{p}<0.1$ 
Table 8: The Impact of Mexican Repatriation by Skill Level: Individual Level Results

Panel A: $\Delta$ Employment 1930-1940

\begin{tabular}{|c|c|c|c|c|c|c|c|c|}
\hline & \multicolumn{4}{|c|}{ Low Skilled } & \multicolumn{4}{|c|}{ High Skilled } \\
\hline & (1) & $(2)$ & $(3)$ & (4) & $(5)$ & $(6)$ & $(7)$ & (8) \\
\hline Repatriation $_{c}$ & $\begin{array}{c}-0.530^{* * *} \\
(0.140)\end{array}$ & $\begin{array}{c}-0.557^{* * *} \\
(0.144)\end{array}$ & $\begin{array}{c}-0.566^{\text {*** }} \\
(0.149)\end{array}$ & $\begin{array}{c}-0.595^{* * *} \\
(0.150)\end{array}$ & $\begin{array}{c}-0.286^{* * *} \\
(0.109)\end{array}$ & $\begin{array}{c}-0.272^{* *} \\
(0.108)\end{array}$ & $\begin{array}{c}-0.313^{* *} \\
(0.123)\end{array}$ & $\begin{array}{c}-0.295^{* *} \\
(0.123)\end{array}$ \\
\hline Observations & 238,125 & 238,121 & 238,125 & 238,121 & 581,008 & 580,997 & 581,008 & 580,997 \\
\hline Adjusted $R^{2}$ & 0.014 & 0.014 & 0.014 & 0.014 & 0.015 & 0.015 & 0.015 & 0.015 \\
\hline
\end{tabular}

Panel B: Non-Employed $1930 \rightarrow$ Employed 1940

\begin{tabular}{|c|c|c|c|c|c|c|c|c|}
\hline & \multicolumn{4}{|c|}{ Low Skilled } & \multicolumn{4}{|c|}{ High Skilled } \\
\hline & (1) & $(2)$ & $(3)$ & $(4)$ & $(5)$ & $(6)$ & $(7)$ & $(8)$ \\
\hline Repatriation $_{c}$ & $\begin{array}{c}-0.434^{* * *} \\
(0.100)\end{array}$ & $\begin{array}{c}-0.455^{* * *} \\
(0.098)\end{array}$ & $\begin{array}{c}-0.499^{* * *} \\
(0.111)\end{array}$ & $\begin{array}{c}-0.520^{* * *} \\
(0.108)\end{array}$ & $\begin{array}{c}-0.215^{* * *} \\
(0.075)\end{array}$ & $\begin{array}{c}-0.207^{* * *} \\
(0.074)\end{array}$ & $\begin{array}{c}-0.260^{* * *} \\
(0.085)\end{array}$ & $\begin{array}{c}-0.251^{* * *} \\
(0.082)\end{array}$ \\
\hline Observations & 238,125 & 238,121 & 238,125 & 238,121 & 581,008 & 580,997 & 581,008 & 580,997 \\
\hline Adjusted $R^{2}$ & 0.004 & 0.004 & 0.004 & 0.004 & 0.006 & 0.006 & 0.006 & 0.006 \\
\hline
\end{tabular}

Panel C: $\Delta$ Occupational Wage 1930-1940

\begin{tabular}{|c|c|c|c|c|c|c|c|c|}
\hline & \multicolumn{4}{|c|}{ Low Skilled } & \multicolumn{4}{|c|}{ High Skilled } \\
\hline & (1) & $(2)$ & $(3)$ & (4) & $(5)$ & (6) & (7) & $(8)$ \\
\hline Repatriation $_{c}$ & $\begin{array}{c}0.081 \\
(0.309)\end{array}$ & $\begin{array}{c}0.035 \\
(0.310)\end{array}$ & $\begin{array}{c}0.098 \\
(0.351)\end{array}$ & $\begin{array}{c}0.042 \\
(0.349)\end{array}$ & $\begin{array}{c}-0.252^{* *} \\
(0.115)\end{array}$ & $\begin{array}{c}-0.302^{* * *} \\
(0.114)\end{array}$ & $\begin{array}{c}-0.287^{* *} \\
(0.143)\end{array}$ & $\begin{array}{c}-0.349^{* *} \\
(0.142)\end{array}$ \\
\hline Observations & 218,688 & 218,685 & 218,688 & 218,685 & 540,481 & 540,470 & 540,481 & 540,470 \\
\hline Adjusted $R^{2}$ & 0.059 & 0.059 & 0.059 & 0.059 & 0.005 & 0.005 & 0.005 & 0.005 \\
\hline 1st Stage $F$ & 31.387 & 32.738 & 30.254 & 31.750 & 25.972 & 27.476 & 18.557 & 19.949 \\
\hline Baseline Controls & $\mathrm{X}$ & & X & & $\mathrm{X}$ & & X & \\
\hline Full Controls & & $\mathrm{X}$ & & $\mathrm{X}$ & & $\mathrm{X}$ & & $\mathrm{X}$ \\
\hline Main IV & $\mathrm{X}$ & $\mathrm{X}$ & & & $\mathrm{X}$ & $\mathrm{X}$ & & \\
\hline Alternative IV & & & $\mathrm{X}$ & $\mathrm{X}$ & & & $\mathrm{X}$ & $\mathrm{X}$ \\
\hline
\end{tabular}

Notes: Each entry shows the estimated coefficient from a regression of a labor market outcome denoted in each panel header on the change in Mexican working age population between 1930 and 1940 relative to total working age population in 1930 and a set of controls. The unit of observation is an individual worker. The sample consists of non-Mexican natives age 18-55, in the labor force, not employed in the army, not an unpaid family worker and not attending school, all in 1930. All regressions control for age, race and marriage and literacy indicators. In addition, baseline and full controls are defined as in Table 3.

$* * * \mathrm{p}<0.01, * * \mathrm{p}<0.05, * \mathrm{p}<0.1$ 
Table 9: Mexican Repartiation and Shrinkage of Low-Skilled Sectors

\begin{tabular}{|c|c|c|c|c|c|c|}
\hline & \multicolumn{6}{|c|}{ Outcome: $\Delta$ Share of Low-Skilled Sectors } \\
\hline & $(1)$ & $(2)$ & $(3)$ & $(4)$ & $(5)$ & $(6)$ \\
\hline Repatriation $_{c}$ & $\begin{array}{c}-0.359^{* * *} \\
(0.119)\end{array}$ & $\begin{array}{c}-0.424^{* * *} \\
(0.127)\end{array}$ & $\begin{array}{c}-0.374^{* *} \\
(0.163)\end{array}$ & $\begin{array}{c}-0.460^{* *} \\
(0.183)\end{array}$ & $\begin{array}{c}-0.124 \\
(0.106)\end{array}$ & $\begin{array}{c}-0.141 \\
(0.099)\end{array}$ \\
\hline 1st stage $F$ & 24.59 & 26.70 & 18.47 & 19.74 & - & - \\
\hline Observations & 680 & 678 & 680 & 678 & 680 & 678 \\
\hline R-squared & 0.208 & 0.215 & 0.206 & 0.211 & 0.217 & 0.228 \\
\hline Baseline Controls & $\mathrm{X}$ & & $\mathrm{X}$ & & $\mathrm{X}$ & \\
\hline Full Controls & & $\mathrm{X}$ & & $\mathrm{X}$ & & $\mathrm{X}$ \\
\hline Main IV & $\mathrm{X}$ & $\mathrm{X}$ & & & & \\
\hline Alternative IV & & & $\mathrm{X}$ & $\mathrm{X}$ & & \\
\hline OLS & & & & & $\mathrm{X}$ & $\mathrm{X}$ \\
\hline State FE & $\mathrm{X}$ & $\mathrm{X}$ & $\mathrm{X}$ & $\mathrm{X}$ & $\mathrm{X}$ & $\mathrm{X}$ \\
\hline Weighted & $\mathrm{X}$ & $\mathrm{X}$ & $\mathrm{X}$ & $\mathrm{X}$ & $\mathrm{X}$ & $\mathrm{X}$ \\
\hline
\end{tabular}

Notes: Each entry shows the estimated coefficient from a regression of the change in low-skilled sectors on the change in Mexican working age population between 1930 and 1940 relative to total working age population in 1930 and a set of controls. The unit of observation is a county. The sample consists of non-Mexican natives age 18-65, in the labor force, not employed in the army, not an unpaid family worker and not attending school. Baseline and full controls are defined as in Table 3. All regressions are weighted by total working age population in 1930. Standard errors are clustered by state economic area.

${ }^{* * *} \mathrm{p}<0.01,{ }^{* *} \mathrm{p}<0.05,{ }^{*} \mathrm{p}<0.1$ 
Table 10: The Impact of Mexican Repatriation: Labor Market Level Results

\begin{tabular}{|c|c|c|c|c|c|c|}
\hline & \multicolumn{6}{|c|}{ Panel A: $\Delta$ Employment 1930-1940 } \\
\hline & $(1)$ & $(2)$ & $(3)$ & $(4)$ & $(5)$ & $(6)$ \\
\hline Repatriation $_{c}$ & $\begin{array}{c}0.246 \\
(0.421)\end{array}$ & $\begin{array}{c}0.454 \\
(0.452)\end{array}$ & $\begin{array}{c}0.320 \\
(0.556)\end{array}$ & $\begin{array}{c}0.589 \\
(0.616)\end{array}$ & $\begin{array}{c}-0.424^{* *} \\
(0.205)\end{array}$ & $\begin{array}{l}-0.385^{*} \\
(0.208)\end{array}$ \\
\hline $\begin{array}{l}\text { 1st stage } F \\
\text { Observations } \\
\text { R-squared }\end{array}$ & $\begin{array}{c}19.40 \\
686 \\
0.267\end{array}$ & $\begin{array}{c}19.56 \\
684 \\
0.273\end{array}$ & $\begin{array}{c}15.48 \\
686 \\
0.263\end{array}$ & $\begin{array}{c}15.67 \\
684 \\
0.263\end{array}$ & $\begin{array}{c}- \\
686 \\
0.285\end{array}$ & $\begin{array}{c}- \\
684 \\
0.301\end{array}$ \\
\hline \multirow{2}{*}{ R-squared } & \multicolumn{6}{|c|}{ Panel B: $\Delta$ Population 1930-1940 } \\
\hline & (1) & (2) & (3) & (4) & (5) & (6) \\
\hline Repatriation $_{c}$ & $\begin{array}{c}0.354 \\
(0.732)\end{array}$ & $\begin{array}{c}0.715 \\
(0.772)\end{array}$ & $\begin{array}{c}0.471 \\
(0.959)\end{array}$ & $\begin{array}{c}0.949 \\
(1.050)\end{array}$ & $\begin{array}{l}-0.633 \\
(0.455)\end{array}$ & $\begin{array}{l}-0.566 \\
(0.456)\end{array}$ \\
\hline $\begin{array}{l}\text { 1st stage } F \\
\text { Observations } \\
\text { R-squared }\end{array}$ & $\begin{array}{c}19.40 \\
686 \\
0.265\end{array}$ & $\begin{array}{c}19.56 \\
684 \\
0.277\end{array}$ & $\begin{array}{c}15.48 \\
686 \\
0.262\end{array}$ & $\begin{array}{c}15.67 \\
684 \\
0.268\end{array}$ & $\begin{array}{c}- \\
686 \\
0.279\end{array}$ & $\begin{array}{c}- \\
684 \\
0.299\end{array}$ \\
\hline & \multicolumn{6}{|c|}{ Panel C: $\Delta$ Occupational Wage 1930-1940 } \\
\hline & $(1)$ & $(2)$ & (3) & (4) & (5) & (6) \\
\hline Repatriation $_{c}$ & $\begin{array}{c}-0.844^{* *} \\
(0.421)\end{array}$ & $\begin{array}{c}-0.921^{* *} \\
(0.448)\end{array}$ & $\begin{array}{l}-1.080^{*} \\
(0.559)\end{array}$ & $\begin{array}{c}-1.203^{* *} \\
(0.605)\end{array}$ & $\begin{array}{l}-0.207 \\
(0.217)\end{array}$ & $\begin{array}{l}-0.193 \\
(0.212)\end{array}$ \\
\hline 1st stage $F$ & 24.59 & 26.70 & 18.47 & 19.74 & - & - \\
\hline Observations & 680 & 678 & 680 & 678 & 680 & 678 \\
\hline R-squared & 0.571 & 0.576 & 0.565 & 0.568 & 0.577 & 0.584 \\
\hline Baseline Controls & $\mathrm{X}$ & & $\mathrm{X}$ & & $\mathrm{X}$ & \\
\hline Full Controls & & $\mathrm{X}$ & & $\mathrm{X}$ & & $\mathrm{X}$ \\
\hline $\begin{array}{l}\text { Main IV } \\
\text { Alternative IV }\end{array}$ & $\mathrm{X}$ & $\mathrm{X}$ & $\mathrm{X}$ & $\mathrm{X}$ & & \\
\hline OLS & & & & & $\mathrm{X}$ & $\mathrm{X}$ \\
\hline State FE & $\mathrm{X}$ & $\mathrm{X}$ & $\mathrm{X}$ & $\mathrm{X}$ & $\mathrm{X}$ & $\mathrm{X}$ \\
\hline Weighted & $\mathrm{X}$ & $\mathrm{X}$ & $\mathrm{X}$ & $\mathrm{X}$ & $\mathrm{X}$ & $\mathrm{X}$ \\
\hline
\end{tabular}

Notes: Each entry shows the estimated coefficient from a regression of an outcome denoted in each panel header on the change in Mexican working age population between 1930 and 1940 relative to total working age population in 1930 and a set of controls. The unit of observation is a county. The sample consists of non-Mexican natives age 18-65, in the labor force, not employed in the army, not an unpaid family worker and not attending school. Baseline and full controls are defined as in Table 3. All regressions are weighted by total working age population in 1930. Standard errors are clustered by state economic area.

${ }^{* * *} \mathrm{p}<0.01,{ }^{* *} \mathrm{p}<0.05,{ }^{*} \mathrm{p}<0.1$ 
Table 11: The Impact of Mexican Repatriation by Skill Level: Labor Market Level Results

\begin{tabular}{|c|c|c|c|c|c|c|c|c|}
\hline & \multicolumn{8}{|c|}{$\Delta$ Employment 1930-1940 } \\
\hline & \multicolumn{4}{|c|}{ Panel A: Low-skilled } & \multicolumn{4}{|c|}{ Panel B: High-skilled } \\
\hline & (1) & $(2)$ & $(3)$ & (4) & (5) & (6) & (7) & (8) \\
\hline Repatriation $_{c}$ & $\begin{array}{c}0.276 \\
(0.177)\end{array}$ & $\begin{array}{c}0.354^{*} \\
(0.197)\end{array}$ & $\begin{array}{c}0.339 \\
(0.243)\end{array}$ & $\begin{array}{c}0.443 \\
(0.274)\end{array}$ & $\begin{array}{l}-0.430 \\
(0.273)\end{array}$ & $\begin{array}{c}-0.277 \\
(0.274)\end{array}$ & $\begin{array}{l}-0.463 \\
(0.330)\end{array}$ & $\begin{array}{c}-0.273 \\
(0.349)\end{array}$ \\
\hline 1st stage $F$ & 19.40 & 19.56 & 15.48 & 15.67 & 19.40 & 19.56 & 15.48 & 15.67 \\
\hline Observations & 686 & 684 & 686 & 684 & 686 & 684 & 686 & 684 \\
\hline R-squared & 0.135 & 0.136 & 0.122 & 0.115 & 0.327 & 0.348 & 0.327 & 0.348 \\
\hline Baseline Controls & $\mathrm{X}$ & & $\mathrm{X}$ & & $\mathrm{X}$ & & $\mathrm{X}$ & \\
\hline Full Controls & & $\mathrm{X}$ & & $\mathrm{X}$ & & $\mathrm{X}$ & & $\mathrm{X}$ \\
\hline Main IV & $\mathrm{X}$ & $\mathrm{X}$ & & & $\mathrm{X}$ & $\mathrm{X}$ & & \\
\hline Alternative IV & & & $\mathrm{X}$ & $\mathrm{X}$ & & & $\mathrm{X}$ & $\mathrm{X}$ \\
\hline State FE & $\mathrm{X}$ & $\mathrm{X}$ & $\mathrm{X}$ & $\mathrm{X}$ & $\mathrm{X}$ & $\mathrm{X}$ & $\mathrm{X}$ & $\mathrm{X}$ \\
\hline Weighted & $\mathrm{X}$ & $\mathrm{X}$ & $\mathrm{X}$ & $\mathrm{X}$ & $\mathrm{X}$ & $\mathrm{X}$ & $\mathrm{X}$ & $\mathrm{X}$ \\
\hline
\end{tabular}

Notes: Each entry shows the estimated coefficient from a regression of the 1930-40 change in employment relative to total working age population in 1930 on the change in Mexican working age population between 1930 and 1940 relative to total working age population in 1930 and a set of controls. The unit of observation is a county. The sample consists of non-Mexican natives age 18-65, in the labor force, not employed in the army, not an unpaid family worker and not attending school. Baseline and full controls are defined as in Table 3. All regressions are weighted by total working age population in 1930. Standard errors are clustered by state economic area.

${ }^{* * *} \mathrm{p}<0.01,{ }^{* *} \mathrm{p}<0.05,{ }^{*} \mathrm{p}<0.1$ 
Table 12: The Impact of Mexican Repatriation on Internal Out-Migration: Individual Level Results

\begin{tabular}{|c|c|c|c|c|c|c|}
\hline & \multicolumn{6}{|c|}{ Panel A: Low-Skilled } \\
\hline & $(1)$ & $(2)$ & $(3)$ & $(4)$ & $(5)$ & (6) \\
\hline \multirow[t]{2}{*}{ Repatriation $_{c}$} & $0.942^{* * *}$ & $0.943^{* * *}$ & $0.941^{* *}$ & $0.942^{* *}$ & 0.210 & 0.210 \\
\hline & $(0.339)$ & $(0.339)$ & $(0.367)$ & $(0.367)$ & $(0.179)$ & $(0.179)$ \\
\hline Observations & 581,008 & 580,997 & 581,008 & 580,997 & 581,008 & 580,997 \\
\hline \multirow[t]{3}{*}{ Adjusted $R^{2}$} & 0.029 & 0.029 & 0.029 & 0.029 & 0.057 & 0.057 \\
\hline & \multicolumn{6}{|c|}{ Panel B: High-Skilled } \\
\hline & $(1)$ & $(2)$ & $(3)$ & $(4)$ & $(5)$ & (6) \\
\hline \multirow{2}{*}{ Repatriation $_{c}$} & $0.986^{* * *}$ & $0.931^{* * *}$ & $1.088^{* * *}$ & $1.022^{* * *}$ & $0.403^{* * *}$ & $0.384^{* * *}$ \\
\hline & $(0.322)$ & $(0.311)$ & $(0.355)$ & $(0.344)$ & $(0.144)$ & $(0.142)$ \\
\hline Observations & $1,281,290$ & $1,281,267$ & $1,281,290$ & $1,281,267$ & $1,281,290$ & $1,281,267$ \\
\hline Adjusted $R^{2}$ & 0.023 & 0.024 & 0.023 & 0.024 & 0.044 & 0.044 \\
\hline 1st Stage $F$ & 30.960 & 30.960 & 26.206 & 26.206 & - & - \\
\hline Baseline Controls & $\mathrm{X}$ & & $\mathrm{X}$ & & $\mathrm{X}$ & \\
\hline Full Controls & & $\mathrm{X}$ & & $\mathrm{X}$ & & $\mathrm{X}$ \\
\hline Main IV & $\mathrm{X}$ & $\mathrm{X}$ & & & & \\
\hline Alternative IV & & & $\mathrm{X}$ & $\mathrm{X}$ & & \\
\hline OLS & & & & & $\mathrm{X}$ & $\mathrm{X}$ \\
\hline
\end{tabular}

Notes: Each entry shows the estimated coefficient from a regression of an indicator for residing in the same county in 1930 and 1940 on the change in Mexican working age population between 1930 and 1940 relative to total working age population in 1930 and a set of controls. The unit of observation is an individual worker. The sample consists of non-Mexican natives age 18-55, in the labor force, not employed in the army, not an unpaid family worker and not attending school, all in 1930. All regressions control for age, race and marriage and literacy indicators. In addition, baseline and full controls are defined as in Table 3 . ${ }^{* * *} \mathrm{p}<0.01,{ }^{* *} \mathrm{p}<0.05,{ }^{*} \mathrm{p}<0.1$ 
Table 13: Ex-post Mexican Repatriation and In-Migration: Individual Level Results

\begin{tabular}{|c|c|c|c|c|c|c|}
\hline & \multicolumn{6}{|c|}{ Panel A: Low Skilled } \\
\hline & (1) & $(2)$ & $(3)$ & (4) & $(5)$ & (6) \\
\hline \multirow{2}{*}{ Repatriation $_{c}$} & 1.046 & 1.010 & 0.969 & 0.956 & 0.230 & 0.228 \\
\hline & $(0.931)$ & $(0.959)$ & $(1.030)$ & $(1.064)$ & $(0.510)$ & $(0.517)$ \\
\hline Observations & 235,311 & 235,303 & 235,311 & 235,303 & 235,311 & 235,303 \\
\hline \multirow[t]{3}{*}{ Adjusted $R^{2}$} & 0.017 & 0.018 & 0.017 & 0.018 & 0.218 & 0.218 \\
\hline & \multicolumn{6}{|c|}{ Panel B: High Skilled } \\
\hline & (1) & $(2)$ & $(3)$ & (4) & (5) & (6) \\
\hline \multirow{2}{*}{ Repatriation $_{c}$} & 0.012 & 0.176 & 0.165 & 0.400 & -0.258 & -0.138 \\
\hline & $(0.997)$ & $(1.030)$ & $(1.082)$ & $(1.129)$ & $(0.515)$ & $(0.521)$ \\
\hline Observations & 701,671 & 701,655 & 701,671 & 701,655 & 701,671 & 701,655 \\
\hline Adjusted $R^{2}$ & 0.039 & 0.042 & 0.039 & 0.041 & 0.285 & 0.287 \\
\hline 1st Stage $F$ & 29.075 & 30.113 & 22.778 & 23.791 & - & - \\
\hline Baseline Controls & $\mathrm{X}$ & & $\mathrm{X}$ & & $\mathrm{X}$ & \\
\hline Full Controls & & $\mathrm{X}$ & & $\mathrm{X}$ & & $\mathrm{X}$ \\
\hline Main IV & $\mathrm{X}$ & $\mathrm{X}$ & & & & \\
\hline Alternative IV & & & $\mathrm{X}$ & $\mathrm{X}$ & & \\
\hline OLS & & & & & $\mathrm{X}$ & $\mathrm{X}$ \\
\hline
\end{tabular}

Notes: Each entry shows the estimated coefficient from a regression of an indicator for internal migration on the change in Mexican working age population between 1930 and 1940 relative to total working age population in 1930 and a set of controls. The unit of observation is an individual worker. All 1930 county level variables are assigned to the county individual is residing in 1940. The sample consists of non-Mexican natives age 18-55, in the labor force, not employed in the army, not an unpaid family worker and not attending school, all in 1930. All regressions control for age, race and marriage and literacy indicators. In addition, baseline and full controls are defined as in Table 3.

${ }^{* * *} \mathrm{p}<0.01,{ }^{* *} \mathrm{p}<0.05,{ }^{*} \mathrm{p}<0.1$ 
Table 14: Mexican Repatriation and Selection of Natives

\begin{tabular}{|c|c|c|c|c|c|c|}
\hline & \multicolumn{6}{|c|}{ Panel A: Selection of Newcomers } \\
\hline & (1) & $(2)$ & $(3)$ & $(4)$ & $(5)$ & $(6)$ \\
\hline Repatriation $_{c}$ & $\begin{array}{l}-0.215^{*} \\
(0.111)\end{array}$ & $\begin{array}{l}-0.220^{*} \\
(0.114)\end{array}$ & $\begin{array}{l}-0.130 \\
(0.124)\end{array}$ & $\begin{array}{l}-0.135 \\
(0.126)\end{array}$ & $\begin{array}{c}-0.119^{* *} \\
(0.055)\end{array}$ & $\begin{array}{c}-0.114^{* *} \\
(0.056)\end{array}$ \\
\hline $\begin{array}{l}\text { 1st stage } F \\
\text { Observations } \\
\text { R-squared }\end{array}$ & $\begin{array}{c}24.59 \\
680 \\
0.353\end{array}$ & $\begin{array}{c}26.70 \\
678 \\
0.355\end{array}$ & $\begin{array}{c}18.47 \\
680 \\
0.357\end{array}$ & $\begin{array}{c}19.74 \\
678 \\
0.360\end{array}$ & $\begin{array}{c}- \\
680 \\
0.357\end{array}$ & $\begin{array}{c}- \\
678 \\
0.360\end{array}$ \\
\hline \multirow{2}{*}{ R-squared } & \multicolumn{6}{|c|}{ Panel B: Selection of Leavers } \\
\hline & $(1)$ & $(2)$ & $(3)$ & $(4)$ & $(5)$ & $(6)$ \\
\hline Repatriation $_{c}$ & $\begin{array}{l}-0.004 \\
(0.078)\end{array}$ & $\begin{array}{l}-0.004 \\
(0.077)\end{array}$ & $\begin{array}{c}0.014 \\
(0.100)\end{array}$ & $\begin{array}{c}0.018 \\
(0.100)\end{array}$ & $\begin{array}{c}0.016 \\
(0.054)\end{array}$ & $\begin{array}{c}0.020 \\
(0.054)\end{array}$ \\
\hline 1st stage $F$ & 19.40 & 19.56 & 15.48 & 15.67 & - & - \\
\hline Observations & 686 & 684 & 686 & 684 & 686 & 684 \\
\hline R-squared & 0.535 & 0.545 & 0.535 & 0.545 & 0.535 & 0.545 \\
\hline Baseline Controls & $\mathrm{X}$ & & $\mathrm{X}$ & & $\mathrm{X}$ & \\
\hline Full Controls & & $\mathrm{X}$ & & $\mathrm{X}$ & & $\mathrm{X}$ \\
\hline Main IV & $\mathrm{X}$ & $\mathrm{X}$ & & & & \\
\hline $\begin{array}{l}\text { Alternative IV } \\
\text { OLS }\end{array}$ & & & $\mathrm{X}$ & $\mathrm{X}$ & $\mathrm{X}$ & $\mathrm{X}$ \\
\hline State FE & $\mathrm{X}$ & $\mathrm{X}$ & $\mathrm{X}$ & $\mathrm{X}$ & $\mathrm{X}$ & $\mathrm{X}$ \\
\hline Weighted & $\mathrm{X}$ & $\mathrm{X}$ & $\mathrm{X}$ & $\mathrm{X}$ & $\mathrm{X}$ & $\mathrm{X}$ \\
\hline
\end{tabular}

Notes: Each entry shows the estimated coefficient from a regression of an outcome denoted in each panel header on the change in Mexican working age population between 1930 and 1940 relative to total working age population in 1930 and a set of controls. The unit of observation is a county. The sample consists of non-Mexican natives age 18-65, in the labor force, not employed in the army, not an unpaid family worker and not attending school. Baseline and full controls are defined as in Table 3. All regressions are weighted by total working age population in 1930. Standard errors are clustered by state economic area.

${ }^{* * *} \mathrm{p}<0.01,{ }^{* *} \mathrm{p}<0.05,{ }^{*} \mathrm{p}<0.1$ 
Table 15: The Impact of Mexican Repatriation on Other Immigrants: Labor Market Level Results

\begin{tabular}{|c|c|c|c|c|c|c|c|c|}
\hline & \multicolumn{8}{|c|}{$\Delta$ Employment 1930-1940 } \\
\hline & \multicolumn{4}{|c|}{ Panel A: Other Immigrants } & \multicolumn{4}{|c|}{ Panel B: Southern European } \\
\hline & $(1)$ & $(2)$ & $(3)$ & $(4)$ & $(1)$ & $(2)$ & $(3)$ & $(4)$ \\
\hline Repatriation $_{c}$ & $\begin{array}{l}-0.089 \\
(0.056)\end{array}$ & $\begin{array}{l}-0.076 \\
(0.058)\end{array}$ & $\begin{array}{l}-0.070 \\
(0.074)\end{array}$ & $\begin{array}{c}-0.059 \\
(0.078)\end{array}$ & $\begin{array}{c}-0.027^{*} \\
(0.015)\end{array}$ & $\begin{array}{c}-0.021 \\
(0.015)\end{array}$ & $\begin{array}{l}-0.025 \\
(0.018)\end{array}$ & $\begin{array}{l}-0.019 \\
(0.019)\end{array}$ \\
\hline 1st stage $F$ & 19.40 & 19.56 & 15.48 & 15.67 & 19.40 & 19.56 & 15.48 & 15.67 \\
\hline Observations & 686 & 684 & 686 & 684 & 686 & 684 & 686 & 684 \\
\hline R-squared & 0.582 & 0.590 & 0.580 & 0.588 & 0.487 & 0.509 & 0.488 & 0.509 \\
\hline Baseline Controls & $\mathrm{X}$ & & $\mathrm{X}$ & & $\mathrm{X}$ & & $\mathrm{X}$ & \\
\hline Full Controls & & $\mathrm{X}$ & & $\mathrm{X}$ & & $\mathrm{X}$ & & $\mathrm{X}$ \\
\hline Main IV & $\mathrm{X}$ & $\mathrm{X}$ & & & $\mathrm{X}$ & $\mathrm{X}$ & & \\
\hline Alternative IV & & & $\mathrm{X}$ & $\mathrm{X}$ & & & $\mathrm{X}$ & $\mathrm{X}$ \\
\hline State FE & $\mathrm{X}$ & $\mathrm{X}$ & $\mathrm{X}$ & $\mathrm{X}$ & $\mathrm{X}$ & $\mathrm{X}$ & $\mathrm{X}$ & $\mathrm{X}$ \\
\hline Weighted & $\mathrm{X}$ & $\mathrm{X}$ & $\mathrm{X}$ & $\mathrm{X}$ & $\mathrm{X}$ & $\mathrm{X}$ & $\mathrm{X}$ & $\mathrm{X}$ \\
\hline
\end{tabular}

Notes: Each entry shows the estimated coefficient from a regression of the 1930-40 change in employment relative to total working age population in 1930 on the change in Mexican working age population between 1930 and 1940 relative to total working age population in 1930 and a set of controls. The unit of observation is a county. The sample consists of non-Mexican immigrants age 18-65, in the labor force, not employed in the army, not an unpaid family worker and not attending school. Baseline and full controls are defined as in Table 3. All regressions are weighted by total working age population in 1930. Standard errors are clustered by state economic area.

${ }^{* * *} \mathrm{p}<0.01,{ }^{* *} \mathrm{p}<0.05,{ }^{*} \mathrm{p}<0.1$ 


\section{Appendix}

Table A1: The Impact of Mexican Repatriation on Employment: Individual Level Results (Black Only)

\begin{tabular}{|c|c|c|c|c|c|c|}
\hline & \multicolumn{6}{|c|}{ Panel A: $\Delta$ Employment 1930-1940 } \\
\hline & $(1)$ & $(2)$ & $(3)$ & $(4)$ & $(5)$ & $(6)$ \\
\hline \multirow[t]{2}{*}{ Repatriation $_{c}$} & $-0.345^{*}$ & $-0.344^{*}$ & $-0.435^{* *}$ & $-0.437^{*}$ & $-0.368^{* * *}$ & $-0.368^{* * *}$ \\
\hline & $(0.184)$ & $(0.203)$ & $(0.215)$ & $(0.238)$ & $(0.119)$ & $(0.127)$ \\
\hline Observations & 110,102 & 110,102 & 110,102 & 110,102 & 110,102 & 110,102 \\
\hline \multirow[t]{3}{*}{ Adjusted $R^{2}$} & 0.010 & 0.010 & 0.010 & 0.010 & 0.011 & 0.011 \\
\hline & \multicolumn{6}{|c|}{ Panel B: Non-Employed $1930 \rightarrow$ Employed 1940} \\
\hline & (1) & $(2)$ & (3) & $(4)$ & $(5)$ & (6) \\
\hline \multirow{2}{*}{$\begin{array}{l}\text { Repatriation } \\
-0.250^{* *}\end{array}$} & & $-0.352^{* * *}$ & $-0.375^{* * *}$ & $-0.450^{* * *}$ & $-0.483^{* * *}$ & $-0.246^{* *}$ \\
\hline & $(0.128)$ & $(0.134)$ & $(0.160)$ & $(0.164)$ & $(0.103)$ & $(0.110)$ \\
\hline Observations & 110,102 & 110,102 & 110,102 & 110,102 & 110,102 & 110,102 \\
\hline \multirow[t]{3}{*}{ Adjusted $R^{2}$} & 0.017 & 0.017 & 0.017 & 0.017 & 0.020 & 0.020 \\
\hline & \multicolumn{6}{|c|}{ Panel C: Employed $1930 \rightarrow$ Non-Employed 1940} \\
\hline & (1) & $(2)$ & (3) & (4) & $(5)$ & (6) \\
\hline \multirow{2}{*}{ Repatriation $_{c}$} & -0.104 & -0.135 & -0.171 & -0.215 & $0.113^{*}$ & $0.112^{*}$ \\
\hline & $(0.131)$ & $(0.136)$ & $(0.155)$ & $(0.161)$ & $(0.061)$ & $(0.058)$ \\
\hline Observations & 110,102 & 110,102 & 110,102 & 110,102 & 110,102 & 110,102 \\
\hline \multirow[t]{3}{*}{ Adjusted $R^{2}$} & 0.002 & 0.002 & 0.002 & 0.002 & 0.004 & 0.004 \\
\hline & \multicolumn{6}{|c|}{ Panel D: $\Delta$ Self-Employment 1930-1940 } \\
\hline & (1) & $(2)$ & $(3)$ & $(4)$ & (5) & (6) \\
\hline \multirow[t]{2}{*}{ Repatriation ${ }_{c}$} & -0.496 & -0.487 & -0.609 & -0.547 & -0.135 & -0.183 \\
\hline & $(0.367)$ & $(0.368)$ & $(0.477)$ & $(0.471)$ & $(0.223)$ & $(0.222)$ \\
\hline Observations & 110,102 & 110,102 & 110,102 & 110102 & 110,102 & 110,102 \\
\hline Adjusted $R^{2}$ & 0.052 & 0.053 & 0.052 & 0.053 & 0.063 & 0.063 \\
\hline 1st Stage $F$ & 37.105 & 36.117 & 27.063 & 27.039 & - & - \\
\hline Baseline Controls & $\mathrm{X}$ & & $\mathrm{X}$ & & $\mathrm{X}$ & \\
\hline Full Controls & & $\mathrm{X}$ & & $\mathrm{X}$ & & $\mathrm{X}$ \\
\hline Main IV & $\mathrm{X}$ & $\mathrm{X}$ & & & & \\
\hline Alternative IV & & & $\mathrm{X}$ & $\mathrm{X}$ & & \\
\hline OLS & & & & & $\mathrm{X}$ & $\mathrm{X}$ \\
\hline
\end{tabular}

Notes: Each entry shows the estimated coefficient from a regression of a labor market outcome denoted in each panel header on the change in Mexican working age population between 1930 and 1940 relative to total working age population in 1930 and a set of controls. The unit of observation is an individual worker. The sample consists of black non-Mexican natives age 18-55, in the labor force, not employed in the army, not an unpaid family worker and not attending school, all in 1930. All regressions control for age, and marriage and literacy indicators. In addition, baseline and full controls are defined as in Table 3 . ${ }^{* * *} \mathrm{p}<0.01,{ }^{* *} \mathrm{p}<0.05,{ }^{*} \mathrm{p}<0.1$ 
Table A2: The Impact of Mexican Repatriation on Occupational Standing: Individual Level Results (Black Only)

\begin{tabular}{|c|c|c|c|c|c|c|}
\hline & \multicolumn{6}{|c|}{ Panel A: $\Delta$ Occupational Wage 1930-1940 } \\
\hline & $(1)$ & $(2)$ & $(3)$ & $(4)$ & $(5)$ & $(6)$ \\
\hline \multirow[t]{2}{*}{ Repatriation $_{c}$} & -0.274 & -0.119 & -0.429 & -0.209 & -1.331 & -1.277 \\
\hline & $(1.287)$ & $(1.312)$ & $(1.519)$ & $(1.544)$ & $(0.856)$ & $(0.875)$ \\
\hline Observations & 92,263 & 92,263 & 92,263 & 92,263 & 922,63 & 92,263 \\
\hline \multirow[t]{3}{*}{ Adjusted $R^{2}$} & 0.065 & 0.065 & 0.065 & 0.065 & 0.079 & 0.080 \\
\hline & \multicolumn{6}{|c|}{ Panel B: $\Delta$ Occupational Score 1930-1940 } \\
\hline & $(1)$ & $(2)$ & $(3)$ & $(4)$ & $(5)$ & $(6)$ \\
\hline \multirow[t]{2}{*}{ Repatriation $_{c}$} & 0.076 & 0.026 & 0.056 & -0.008 & -0.183 & -0.209 \\
\hline & $(0.225)$ & $(0.230)$ & $(0.316)$ & $(0.313)$ & $(0.140)$ & $(0.141)$ \\
\hline Observations & 92,347 & 92,347 & 92,347 & 92,347 & 92347 & 92,347 \\
\hline Adjusted $R^{2}$ & 0.020 & 0.021 & 0.020 & 0.021 & 0.023 & 0.023 \\
\hline 1st Stage $F$ & 34.618 & 33.766 & 24.781 & 23.866 & - & - \\
\hline Baseline Controls & $\mathrm{X}$ & & $\mathrm{X}$ & & $\mathrm{X}$ & \\
\hline Full Controls & & $\mathrm{X}$ & & $\mathrm{X}$ & & $\mathrm{X}$ \\
\hline Main IV & $\mathrm{X}$ & $\mathrm{X}$ & & & & \\
\hline Alternative IV & & & $\mathrm{X}$ & $\mathrm{X}$ & & \\
\hline OLS & & & & & $\mathrm{X}$ & $\mathrm{X}$ \\
\hline
\end{tabular}

Notes: Each entry shows the estimated coefficient from a regression of a labor market outcome denoted in each panel header on the change in Mexican working age population between 1930 and 1940 relative to total working age population in 1930 and a set of controls. The unit of observation is an individual worker. The sample consists of black non-Mexican natives age 18-55, in the labor force, not employed in the army, not an unpaid family worker and not attending school, all in 1930. All regressions control for age, and marriage and literacy indicators. In addition, baseline and full controls are defined as in Table 3.

${ }^{* * *} \mathrm{p}<0.01,{ }^{* *} \mathrm{p}<0.05,{ }^{*} \mathrm{p}<0.1$ 
Table A3: The Impact of Mexican Repatriation: Labor Market Level Results (Unweighted)

\begin{tabular}{|c|c|c|c|c|c|c|}
\hline & \multicolumn{6}{|c|}{ Panel A: $\Delta$ Employment 1930-1940 } \\
\hline & $(1)$ & $(2)$ & $(3)$ & $(4)$ & $(5)$ & $(6)$ \\
\hline Repatriation $_{c}$ & $\begin{array}{c}0.660 \\
(0.520)\end{array}$ & $\begin{array}{c}0.568 \\
(0.677)\end{array}$ & $\begin{array}{c}0.780 \\
(0.690)\end{array}$ & $\begin{array}{c}0.698 \\
(0.917)\end{array}$ & $\begin{array}{l}-0.166 \\
(0.398)\end{array}$ & $\begin{array}{l}-0.199 \\
(0.440)\end{array}$ \\
\hline 1st stage $F$ & 10.51 & 9.68 & 11.36 & 9.90 & & \\
\hline \multirow[t]{3}{*}{$\begin{array}{l}\text { Observations } \\
\text { R-squared }\end{array}$} & $\begin{array}{c}686 \\
0.110\end{array}$ & $\begin{array}{c}684 \\
0.149\end{array}$ & $\begin{array}{c}686 \\
0.103\end{array}$ & $\begin{array}{c}684 \\
0.142\end{array}$ & $\begin{array}{c}686 \\
0.133\end{array}$ & $\begin{array}{c}684 \\
0.168\end{array}$ \\
\hline & \multicolumn{6}{|c|}{ Panel B: $\Delta$ Occupational Wage 1930-1940 } \\
\hline & $(1)$ & $(2)$ & $(3)$ & $(4)$ & $(5)$ & $(6)$ \\
\hline Repatriation $_{c}$ & $\begin{array}{l}-0.520 \\
(0.535)\end{array}$ & $\begin{array}{l}-0.388 \\
(0.489)\end{array}$ & $\begin{array}{l}-0.533 \\
(0.608)\end{array}$ & $\begin{array}{l}-0.418 \\
(0.576)\end{array}$ & $\begin{array}{l}-0.165 \\
(0.311)\end{array}$ & $\begin{array}{l}-0.076 \\
(0.261)\end{array}$ \\
\hline 1st stage $F$ & 18.53 & 19.01 & 22.07 & 21.46 & & \\
\hline Observations & 680 & 678 & 680 & 678 & 680 & 678 \\
\hline R-squared & 0.389 & 0.411 & 0.389 & 0.411 & 0.392 & 0.414 \\
\hline Baseline Controls & $\mathrm{X}$ & & $\mathrm{X}$ & & $\mathrm{X}$ & \\
\hline $\begin{array}{l}\text { Full Controls } \\
\text { Main IV }\end{array}$ & $\mathrm{X}$ & $\begin{array}{l}X \\
X\end{array}$ & & $X$ & & $\mathrm{X}$ \\
\hline $\begin{array}{l}\text { Alternative IV } \\
\text { OLS }\end{array}$ & & & $\mathrm{X}$ & $\mathrm{X}$ & $X$ & $\mathrm{X}$ \\
\hline $\begin{array}{l}\text { State FE } \\
\text { Weighted }\end{array}$ & $\mathrm{X}$ & $\mathrm{X}$ & $\mathrm{X}$ & $\mathrm{X}$ & $\mathrm{X}$ & $\mathrm{X}$ \\
\hline
\end{tabular}

Notes: Each entry shows the estimated coefficient from a regression of an outcome denoted in each panel header on the change in Mexican working age population between 1930 and 1940 relative to total working age population in 1930 and a set of controls. The unit of observation is a county. The sample consists of non-Mexican natives age 18-65, in the labor force, not employed in the army, not an unpaid family worker and not attending school. Baseline and full controls are defined as in Table 3. Standard errors are clustered by state economic area.

${ }^{* * *} \mathrm{p}<0.01,{ }^{* *} \mathrm{p}<0.05,{ }^{*} \mathrm{p}<0.1$ 
Table A4: The Impact of Mexican Repatriation: Labor Market Level Results (Male Only)

\begin{tabular}{|c|c|c|c|c|c|c|}
\hline & \multicolumn{6}{|c|}{ Panel A: $\Delta$ Employment 1930-1940 } \\
\hline & $(1)$ & $(2)$ & $(3)$ & $(4)$ & $(5)$ & (6) \\
\hline Repatriation $_{c}$ & $\begin{array}{c}0.210 \\
(0.292)\end{array}$ & $\begin{array}{c}0.341 \\
(0.313)\end{array}$ & $\begin{array}{c}0.276 \\
(0.389)\end{array}$ & $\begin{array}{c}0.447 \\
(0.428)\end{array}$ & $\begin{array}{c}-0.236 \\
(0.187)\end{array}$ & $\begin{array}{c}-0.217 \\
(0.187)\end{array}$ \\
\hline 1st stage $F$ & 24.59 & 26.70 & 18.47 & 19.74 & & \\
\hline \multirow[t]{3}{*}{$\begin{array}{l}\text { Observations } \\
\text { R-squared }\end{array}$} & $\begin{array}{c}680 \\
0.260\end{array}$ & $\begin{array}{c}678 \\
0.268\end{array}$ & $\begin{array}{c}680 \\
0.256\end{array}$ & $\begin{array}{c}678 \\
0.259\end{array}$ & $\begin{array}{c}680 \\
0.274\end{array}$ & $\begin{array}{c}678 \\
0.289\end{array}$ \\
\hline & \multicolumn{6}{|c|}{ Panel B: $\Delta$ Occupational Wage 1930-1940 } \\
\hline & $(1)$ & $(2)$ & $(3)$ & $(4)$ & $(5)$ & (6) \\
\hline Repatriation $_{c}$ & $\begin{array}{l}-0.803 \\
(0.529)\end{array}$ & $\begin{array}{c}-0.881 \\
(0.564)\end{array}$ & $\begin{array}{l}-1.007 \\
(0.695)\end{array}$ & $\begin{array}{l}-1.129 \\
(0.751)\end{array}$ & $\begin{array}{c}-0.234 \\
(0.231)\end{array}$ & $\begin{array}{c}-0.215 \\
(0.226)\end{array}$ \\
\hline 1st stage $F$ & 24.59 & 26.70 & 18.47 & 19.74 & & \\
\hline Observations & 680 & 678 & 680 & 678 & 680 & 678 \\
\hline R-squared & 0.504 & 0.511 & 0.499 & 0.504 & 0.510 & 0.519 \\
\hline Baseline Controls & $\mathrm{X}$ & & $\mathrm{X}$ & & $\mathrm{x}$ & \\
\hline Full Controls & & $\mathrm{X}$ & & $\mathrm{X}$ & & $\mathrm{X}$ \\
\hline Main IV & $\mathrm{X}$ & $\mathrm{X}$ & & & & \\
\hline $\begin{array}{l}\text { Alternative IV } \\
\text { OLS }\end{array}$ & & & $\mathrm{X}$ & $\mathrm{X}$ & $\mathrm{X}$ & $\mathrm{X}$ \\
\hline State FE & $\mathrm{X}$ & $\mathrm{X}$ & $\mathrm{X}$ & $\mathrm{X}$ & $\begin{array}{l}X \\
X\end{array}$ & $\begin{array}{l}X \\
X\end{array}$ \\
\hline Weighted & $\mathrm{X}$ & $\mathrm{X}$ & $\mathrm{X}$ & $\mathrm{X}$ & $\mathrm{X}$ & $\mathrm{X}$ \\
\hline
\end{tabular}

Notes: Each entry shows the estimated coefficient from a regression of an outcome denoted in each panel header on the change in Mexican working age population between 1930 and 1940 relative to total working age population in 1930 and a set of controls. The unit of observation is a county. The sample consists of non-Mexican male natives age 18-65, in the labor force, not employed in the army, not an unpaid family worker and not attending school. Baseline and full controls are defined as in Table 3. All regressions are weighted by total working age population in 1930. Standard errors are clustered by state economic area. ${ }^{* * *} \mathrm{p}<0.01,{ }^{* *} \mathrm{p}<0.05,{ }^{*} \mathrm{p}<0.1$ 